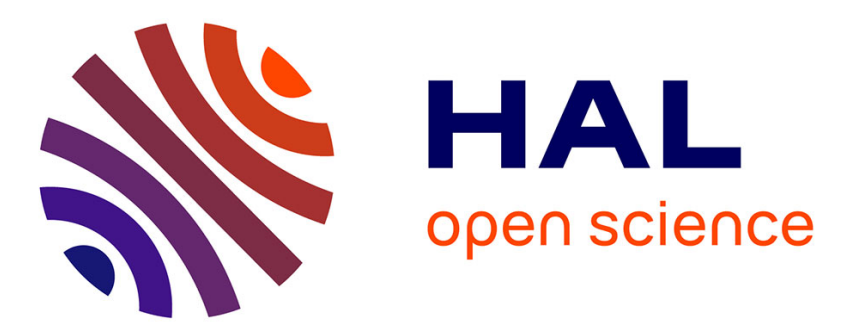

\title{
Functions of epidermal growth factor receptor in cisplatin response of thyroid cells
}

\author{
Antonella Muscella, Loredana Urso, Nadia Calabriso, Carla Vetrugno, \\ Francesco Paolo Fanizzi, Carlo Storelli, Santo Marsigliante
}

\section{To cite this version:}

Antonella Muscella, Loredana Urso, Nadia Calabriso, Carla Vetrugno, Francesco Paolo Fanizzi, et al.. Functions of epidermal growth factor receptor in cisplatin response of thyroid cells. Biochemical Pharmacology, 2009, 77 (6), pp.979. 10.1016/j.bcp.2008.12.001 . hal-00531850

\section{HAL Id: hal-00531850 https://hal.science/hal-00531850}

Submitted on 4 Nov 2010

HAL is a multi-disciplinary open access archive for the deposit and dissemination of scientific research documents, whether they are published or not. The documents may come from teaching and research institutions in France or abroad, or from public or private research centers.
L'archive ouverte pluridisciplinaire HAL, est destinée au dépôt et à la diffusion de documents scientifiques de niveau recherche, publiés ou non, émanant des établissements d'enseignement et de recherche français ou étrangers, des laboratoires publics ou privés. 


\section{Accepted Manuscript}

Title: Functions of epidermal growth factor receptor in cisplatin response of thyroid cells

Authors: Antonella Muscella, Loredana Urso, Nadia Calabriso, Carla Vetrugno, Francesco Paolo Fanizzi, Carlo Storelli, Santo Marsigliante

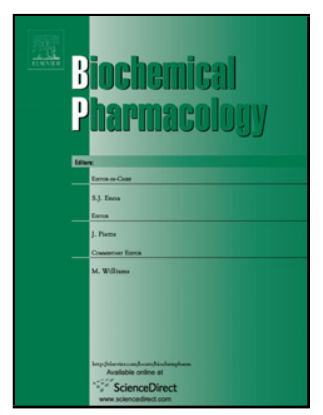

PII: S0006-2952(08)00863-0

DOI: doi:10.1016/j.bcp.2008.12.001

Reference: BCP 10032

To appear in: $\quad B C P$

Received date: $\quad 22-10-2008$

Revised date: $\quad 28-11-2008$

Accepted date: $\quad 1-12-2008$

Please cite this article as: Muscella A, Urso L, Calabriso N, Vetrugno C, Fanizzi FP, Storelli C, Marsigliante S, Functions of epidermal growth factor receptor in cisplatin response of thyroid cells, Biochemical Pharmacology (2008), doi:10.1016/j.bcp.2008.12.001

This is a PDF file of an unedited manuscript that has been accepted for publication. As a service to our customers we are providing this early version of the manuscript. The manuscript will undergo copyediting, typesetting, and review of the resulting proof before it is published in its final form. Please note that during the production process errors may be discovered which could affect the content, and all legal disclaimers that apply to the journal pertain. 


\title{
FUNCTIONS OF EPIDERMAL GROWTH FACTOR RECEPTOR IN CISPLATIN RESPONSE OF THYROID CELLS
}

\section{Antonella Muscella, Loredana Urso, Nadia Calabriso, Carla Vetrugno, Francesco \\ Paolo Fanizzi, Carlo Storelli \& Santo Marsigliante \\ from the "Department of Biological and Environmental Sciences and Technologies \\ (Di.S.Te.B.A.), Università del Salento -Lecce, Italy"}

Key words: EGFR, p38/MAPK, PKC-ع, MMP-2, ROS, cisplatin, thyroid, PC Cl3

\author{
alphabetical list of non-standard abbreviations \\ DAPI, 4,6-diammine-2-phenylindol \\ $E C L$, enhanced chemiluminescence \\ EGFR, epidermal growth factor receptor \\ ERK, extracellular signal-regulated kinase \\ MAPK, mitogen-activated protein kinase \\ MEK, MAPK/ERK kinase \\ MTT, 3-(4,5-dimethylthiazol-2-yl)-2,5-diphenol tetrazolium bromide \\ PARP, poly(ADP-ribose) polymerase \\ PBS, phosphate-buffered saline \\ PVDF, polyvinylidene difluoride membrane \\ SDS, sodium dodecyl sulphate \\ siRNA, small interfering RNA \\ SRB, sulforhodamine $B$ \\ $\underline{\text { Running title: }}$ Role of EGFR in cisplatin-treated cells
}

Corresponding author: S. Marsigliante; email: santo.marsigliante@ unile.it 


\section{ABSTRACT}

Epidermal growth factor receptor (EGFR) signal transduction pathway has been reported to play a vital role in the biologic progression of several tumors and as targets for therapeutic intervention. We have investigated the role of EGFR in the thyroid $\mathrm{PC} \mathrm{Cl} 3$ cells response to the chemo-therapeutic agent cisplatin. It was found that cisplatin provoked (1) the activation (phosphorylation) and internalization of EGFR, (2) the phosphorylation of MAPK/p38, (3) the activation of PKC- $\varepsilon$, (4) the enhancement of MMP-2 expression and activity, (5) the generation of ROS and (6) the activation of the apoptotic intrinsic pathway. Inhibition or down regulation of EGFR reduced (1) the phosphorylation of MAPK/p38 (2) the cisplatinprovoked activation of PKC- $\varepsilon$, and (3) the activation of caspase-7 and PARP cleavage and the overall cells sensitivity to cisplatin. PKC- $\varepsilon$ inhibition achieved by siRNA blocked MAPK/p38 activation and significantly increased the cell resistance to cisplatin. Finally, when the cisplatin-induced ROS generation was blocked by using $\mathrm{NAD}(\mathrm{P}) \mathrm{H}$ oxidase inhibitors, a decrease in cisplatin-induced MMP-2 enhancement, MAPK/p38 and EGFR activation, and caspase-7 proteolysis occurred.

In conclusion, these findings supported a model in which cisplatin provokes an oxidantinduced MMP-2-dependent EGFR transactivation responsible for the induction of cell apoptosis, a process ascribable to the intracellular signalling of PKC- $\varepsilon$ and MAPK/p38. 


\section{Introduction}

Medical treatment of cancer is based on cytotoxic drugs that determine cell killing by acting on cellular targets that are generally common to both cancer and normal cells. The chemo-therapeutic agent cisplatin (cis-diamminedichloroplatinum) is widely employed for treatment of human cancer, and is a potent inducer of growth arrest and/or apoptosis in most cell types. Cisplatin, doxorubicin, and taxol are among the cytotoxic drugs that have elicited the best response in patients affected by poorly differentiated thyroid cancers (PDTC) and undifferentiated (anaplastic) thyroid carcinomas (UTC); however, overall the rate of response to the different chemotherapeutic regimens is generally low, and the rapid occurrence of resistance leads to an often fatal relapse of the disease [1-3]. Another major limitation of cisplatin chemotherapy is serious toxicity. Cisplatin toxicological profiles are similar to many anticancer agents: nephrotoxicity, neurotoxicity, and emesis. Much evidence, however, has been gathered in recent years suggesting that cisplatin has major effects on the endocrine system, particularly the hypothalamic-pituitary-axis. Cisplatin activates nuclear as well as cytoplasmatic signalling pathways involved in regulation of the cell cycle, damage repair and programmed cell death and it also activates a membraneintegrated protein, the epidermal growth factor receptor (EGFR) [4]. EGFR, commonly expressed in a variety of human tumours, thyroid cancer included [5], provides a target for cancer therapy since EGFR-tyrosine kinase inhibitors caused growth inhibition of tumours and enhancement of the activity of a number of cytotoxic drugs $[6,7]$. In response to cisplatin, EGFR has been implicated in the activation of downstream events [8], including extracellular signal-regulated kinase (ERK) [4]. In this context, the mitogen-activated protein kinase (MAPK) cascades, involved in both growth factor and stress response signaling, play a complex and controversial role in determining the ultimate fate of the cells depending on cell type and molecular background. For example, ERK and p38 are structurally related but biochemically and functionally distinct. Whereas ERK predominantly confers survival advantage to cells during most stress conditions in various types of cells, p38 is associated with cell death [9]. Several signalling transduction pathways activated by cisplatin, such as the MAPK pathway components, have been correlated to matrix metalloproteinases (MMPs) activation and expression [10]; furthermore, the anti-invasive properties of cisplatin associated with decrease in MMPs activity have also been reported [11]. Stimulation of MMPs production in some cancer cells appeared to be EGFR-dependent [12], whilst, on the other hand, among multiple mechanisms for EGFR transactivation, the autocrine/paracrine release of soluble EGF 
ligands cleaved by MMPs, is also described [13,14]. Finally, the cisplatin-induced cytotoxicity seems to be closely associated with the increased production of reactive oxygen species (ROS) [15] and ROS contribute to cell death partly through effects on various cellular signalling pathways, including the mitogen-activated protein kinase (MAPK) pathway [16].

In previous studies we have described the effects of cisplatin in fully differentiated thyroid PC Cl3 cells and in cancerous PC E1Araf cells [17,18], which are PC $\mathrm{Cl} 3$ cells completely transformed by the combination of adenovirus E1A gene and raf oncogene $[19,20]$. It was shown that $\mathrm{PC} \mathrm{Cl3}$ cells are most sensitive to cisplatin with IC50 values of $5.2 \mu \mathrm{M}$, after $72 \mathrm{~h}$ of cisplatin exposure, and that ERK has a protective role in cisplatininduced apoptosis. With the present study we carried on with the study of the signalling brought about by cisplatin and assessed the relevance of EGFR and/or p38/MAPK in the sensitivity of normal PC Cl3 thyroid cells to cisplatin. Other authors have published some of the findings presented here when working with various cancer tissues and cells. However, we have obtained such results for the first time using normal thyroid cells where the effects of cisplatin may be different and opposite to thyroid cancer cells $[17,18]$. In addition, and even though thyroid cells are constantly exposed to ROS that are physiologically necessary and closely associated with thyroid hormone synthesis, we determined whether cisplatin-induced EGFR activation was correlated to ROS generation. 


\section{MATERIALS AND METHODS}

2.1 Reagents. The PKC inhibitors GF109203X, Gö6976, and the PKC- $\varepsilon$-selective translocation inhibitor $\varepsilon \mathrm{V} 1$ were obtained from Calbiochem (Darmstadt, Germany). PKC- $\varepsilon$, caspase-3, caspase-7, porin, Bid, Bax, Bcl-2, PARP, phospho-specific ERK1 and ERK2, polyclonal unphosphorylated EGFR and phosphorylated (on Tyr 1173) EGFR ( $p$-EGFR) antibodies, goat anti-rabbit IgG conjugated with peroxidase, as well as control antibodies, were obtained from Santa Cruz Biotechnology, Santa Cruz, CA, USA. Phospho-specific p38/MAPK (Thr180/Tyr182) and total (phosphorylated and unphosphorylated) p38/MAPK antibodies were obtained from Cell Signaling Technology (Celbio, Pero, Milan, Italy). The inhibitors of NADPH oxidase, diphenyleneiodonium (DPI) and apocynin, were obtained from Sigma (Milan, Italy).

2.2 Cell lines. $\mathrm{PC} \mathrm{Cl} 3$, a rat differentiated thyroid cell line, was grown in Coon's modified Ham's F-12 medium (Celbio, Pero, Milan, Italy) supplemented with 5\% calf serum (Sigma, Milan, Italy) and a mixture of hormones and growth factors (insulin $1 \mu \mathrm{g} / \mathrm{ml} ; \mathrm{TSH} 1 \mathrm{mlU} / \mathrm{ml}$; glycylhistidyl- L-lysine $10 \mathrm{ng} / \mathrm{ml}$; human transferring $5 \mu \mathrm{g} / \mathrm{ml}$; cortisone $10 \mathrm{nM}$; somatostatin $10 \mathrm{ng} / \mathrm{ml}$; all from Sigma).

2.3 Preparation of sub cellular fraction. To obtain protein cell extracts, cells were washed twice in ice-cold PBS and harvested in $1 \mathrm{ml}$ of PBS. The samples were centrifuged for $30 \mathrm{~s}$ at $10,000 \mathrm{~g}$, and cell pellets were resuspended in the following buffer (in $\mathrm{mM}$ ): 20 Tris- $\mathrm{HCl}, \mathrm{pH} 8$, containing $420 \mathrm{NaCl}, 2$ EDTA, $2 \mathrm{Na}_{3} \mathrm{VO}_{4}$, and 0,2\% Nonidet P-40, 10\% glycerol, supplemented with a cocktail of protease inhibitors. After a 10 min incubation on ice, cells were passed several times through a 20 gauge syringe and then centrifuged at $13,000 \mathrm{~g}$ for $10 \mathrm{~min}$ at $4^{\circ} \mathrm{C}$. Other samples were centrifuged $(100,000 \mathrm{~g})$ for $40 \mathrm{~min}$ at $4{ }^{\circ} \mathrm{C}$. The resultant supernatant is referred to as the cytosolic fraction. The pellet was solubilized in buffer $B$ (in mM, 20 Tris- $\mathrm{HCl}, \mathrm{pH} 7.5,150 \mathrm{NaCl}, 1$ EGTA, 1 EDTA, and protease inhibitors) containing $1 \%$ Nonidet P-40. We evaluated the $\mathrm{Na}^{+} / \mathrm{K}^{+}$-ATPase activity using a coupled enzyme assay method [21] to determine the purity of the cell membrane fraction used for immunoblotting. The enrichment factor (enzyme activities of final purified membrane pellet and cytosol compared with those of the initial homogenate) were $33 \pm 2.2$ and not determined. Moreover, lactate dehydrogenase activity (a marker enzyme for the cytoplasm) was determined by measuring the decrease at $340 \mathrm{~nm}$ due to 
the oxidation of $\mathrm{NADH}$ [22]. The reaction buffer contained $50 \mathrm{mM}$ HEPES, $\mathrm{pH} 7.5,8 \mathrm{mM}$ sodium pyruvate, $0.2 \mathrm{mM} \mathrm{NADH}$ and the protein sample in a $1 \mathrm{ml}$ volume. Sodium pyruvate was added last to minimize non-specific NADH oxidation. The specific activity of $\mathrm{LDH}$ in the cytosol was 13.1 times higher than that in the homogenate.

Nuclei were pelleted by centrifugation at 2,000 $\mathrm{g}$ for $15 \mathrm{~min}$ at $4{ }^{\circ} \mathrm{C}$ and resuspended in high salt buffer (in mM, 20 Tris- $\mathrm{HCl}, \mathrm{pH} 7.9,420 \mathrm{NaCl}, 10 \mathrm{KCl}, 0.1 \mathrm{Na} 3 \mathrm{VO}_{4}, 1$ EDTA, 1 EGTA, 20\% glycerol, supplemented with a cocktail of protease inhibitors) and sonicated until no nuclei remained intact. The purity of fractions was tested by immunoblotting with antibodies specific to NucP62 (nuclear protein). The mitochondrial fraction was harvested by centrifugation at $10,000 \mathrm{~g}$ for $30 \mathrm{~min}\left(4^{\circ} \mathrm{C}\right)$. The supernatant was harvested as the cytoplasmic fraction (S-100 extract).

Proteins in homogenates and cellular fraction were determined using the Bio-Rad protein assay kit 1 (Milan, Italy). Lyophilised bovine serum albumin was used as a standard.

2.4 Western blot analysis. Proteins in homogenates and cellular fraction were determined using the Bio-Rad protein assay kit 1 (Milan, Italy). Lyophilised bovine serum albumin was used as a standard. Total cell proteins or proteins of the distinct sub cellular fractions were dissolved in SDS sample buffer and separated on $10 \%$ or $15 \%$ SDS gels. Separated proteins were transferred electrophoretically onto polyvinylidene difluoride membrane (PVDF) (Amersham International). Equal protein loading was confirmed by Ponceau $S$ staining. Blots were incubated with specific primary antibodies and the immune complexes were detected using appropriate peroxidase-conjugated secondary antibodies and enhanced chemiluminescent detection reagent ECL (Amersham International). Blots were stripped and used for several sequential incubations with control antibodies. Densitometric analysis was carried out on the Western blots using the NIH Image 1.62 software (National Institutes of Health, Bethesda, MD, USA). The pixel intensity for each region was analyzed, the background was subtracted, and the protein expressions were normalized to $\beta$ actin loading control for each lane.

2.5 Design and preparation of small interfering RNA (siRNA). siRNAs were prepared by an in vitro transcription method. Initially, four siRNA- $\varepsilon$ target sites specific to rat PKC- $\varepsilon$ mRNA, and three siRNA-EGFR target sites specific to rat mRNAs as determined by blast analysis, were chosen. A nonspecific siRNA (siRNA-NS) was also designed to serve as a negative control. For each siRNA, sense and antisense templates were designed based 
on each target sequence and partial T7 promoter sequence. All template oligonucleotides were chemically synthesized and PAGE purified. In vitro transcription, annealing, and purification of siRNA duplexes were performed using the protocol supplied with the T7 RiboMAX Express RNAi System (Promega Corporation, Madison, WI, USA). Briefly, approximately $2 \mu \mathrm{g}$ of each single-strand (ss) transcription template was first annealed with the T7 promoter and filled in by Klenow DNA polymerase to form double-strand transcription templates. For preparation of each siRNA duplex, transcription reactions were first performed with separated antisense and sense templates using the T7 RNA polymerase provided with the kit and then annealed to form siRNA duplexes. Then, the siRNA duplex was treated with DNase and RNase to remove the extra nucleotides of transcribed siRNA to meet the structural 3'UUU overhang and 5' phosphate requirement. Immunoblottings were performed 24 and $48 \mathrm{~h}$ post transfection to determine the efficiency of siRNA incorporation in PC Cl3 cells and to measure PKC- $\varepsilon$ and EGFR expression. Quantitative analysis of $\mathrm{PKC}-\varepsilon$ and EGFR expression, as measured by intensity of immunoreactivity, in siRNA-transfected $\mathrm{PC} \mathrm{Cl} 3$ revealed a higher reduction in $\mathrm{PKC}-\varepsilon$ and EGFR expression, with the following sense RNA sequences: 5'GCCCCUAAAGACAAUGAAGTT-3' and 5'-TTACAAACTTTGCGACAGG-3' for PKC- $\varepsilon$ and EGFR respectively. Such reduction in PKC- $\varepsilon$ expression was not revealed in siRNA-NStransfected (nonspecific siRNA, sequence 5'-AAGTTCTCCGAAGTGTGAGAA-3') cells designed to serve as a negative control.

2.6 siRNA transfection. The cells $(50-70 \%$ confluence) were transfected with siRNA duplexes using the protocol supplied with the CodeBreaker siRNA transfection reagent (Promega Corporation, Madison, WI, USA). Briefly, transfection reagent was first diluted into Coon's modified Ham's F12 medium without serum and antibiotics for about $15 \mathrm{~min}$, and then the siRNA-E, siRNA-EGFR and nonsense siRNA (siRNA-NS) duplex were added to the medium to form a lipid-siRNA complex. Following additional 15-min incubation, transfection was initiated by adding the lipid-siRNA complex to 6-well plates. The final concentrations of siRNAs were $10 \mathrm{nM}$.

2.7 Cytotoxicity assay. Cells at $70-80 \%$ confluency were trypsinised $(0.25 \%$ trypsin with $1 \mathrm{mM}$ EDTA), washed and re-suspended in growth medium. $100 \mu \mathrm{l}$ of a cell suspension $\left(10^{5} \mathrm{cells} / \mathrm{ml}\right)$ was added to each well of a $96-$ well plate. After overnight incubation, cells were treated with specific reagents for different incubation periods. 
The conversion of MTT [3-(4,5-dimethylthiazol-2-yl)-2,5-diphenol tetrazolium bromide] by cells was used as an indicator of cell number as previously described [18]. This method measures the reduction of MTT by active mitochondria, which results in a colorimetric change measured at $550 \mathrm{~nm}$ wavelength. Experiments were performed to define the linear range of the assay. A good correlation was observed up to 50,000 cells per well (data not shown).

Increasing concentration of heat-killed cells per well (killed by incubating at $70{ }^{\circ} \mathrm{C}$ for 15 min) caused no significant change in the absorbance; thus, this spectrophotometric method was a valid technique for measuring the number of viable cells. All subsequent experiments performed were within the linear range of the assay.

The percentage cell survival was calculated as the absorbance ratio of treated to untreated cells. The data presented are means \pm standard deviation (SD) from eight replicate wells per microtitre plate, repeated four times.

2.8 Sulforhodamine B (SRB) assay. The SRB assay was carried out as previously described [23]. Briefly, $70 \mu \mathrm{L} 0.4 \%(\mathrm{w} / \mathrm{v})$ sulforhodamine $B$ in $1 \%$ acetic acid solution was added to each well and left at room temperature for $20 \mathrm{~min}$. SRB was removed and the plates washed 5 times with $1 \%$ acetic acid before air drying. Bound SRB was solubilised with $200 \mu \mathrm{l}$ of $10 \mathrm{mM}$ unbuffered Tris-base solution and plates were left on a plate shaker for at least $10 \mathrm{~min}$. Absorbance was measured in a 96 well plate reader at $492 \mathrm{~nm}$. The test optical density (OD) value was defined as the absorbance of each individual well, minus the blank value ('blank' is the mean optical density of the background control wells, $n=8$ ). The percentage survival was calculated as the absorbance ratio of treated to untreated cells. The data presented are means \pm standard deviation (SD) from eight replicate wells per microtitre plate, repeated four times.

2.9 Trypan Blue Dye Exclusion Assay. The cells were seeded in $60 \mathrm{~mm}$ tissue culture dishes $(100,000$ cells $/ \mathrm{ml})$. After overnight incubation, the cells were treated with the concentrations of cisplatin. Cell viability was estimated using the trypan blue exclusion assay and light microscopy.

2.10 Apoptosis analysis. For 4,6-diammine-2-phenylindol (DAPI) staining, cells treated with cisplatin were fixed with $3 \%$ formalin and stained with $1 \mathrm{mg} / \mathrm{ml} \mathrm{DAPI}$ in PBS for 10 min. Cells were mounted on glass slides, covered, and analysed using fluorescence 
microscopy. For statistical analysis of each experiment, 5-10 fields (magnification $X 400$ ) were counted (between 400 and 700 cells in total). The mean \pm SD was calculated and displayed as bar graph.

2.11 MMP-2 Gelatin Zymography. After cisplatin treatment, the culture medium was collected and centrifuged at $14,000 \mathrm{rpm}$ for $5 \mathrm{~min}$ at $4^{\circ} \mathrm{C}$ to remove cells and debris. Each sample was mixed with equal amounts of SDS sample buffer and electrophoresed on $10 \%$ polyacrylamide gels containing $1 \mathrm{mg} / \mathrm{ml}$ gelatin as the protease substrate. Following electrophoresis, gels were placed in Triton X-100 solution (2.5\% Triton X-100 e $50 \mathrm{mM}$ Tris- $\mathrm{HCl} \mathrm{pH} \mathrm{7.4)} \mathrm{for} 1 \mathrm{~h}$ to remove SDS, and then incubated for $16-18 \mathrm{~h}$ at $37^{\circ} \mathrm{C}$ in developing buffer (in mM: 50 Tris base, $200 \mathrm{NaCl}, 5 \mathrm{CaCl}_{2}$, and 1\% Triton X-100, pH 7,4) on a rotary shaker. After incubation, gels were stained in $30 \%$ methanol, $10 \%$ acetic acid, and $0.5 \% \mathrm{w} / \mathrm{v}$ coomassie brilliant blue for $1 \mathrm{~h}$ followed by destaining. Gelatinolytic activity was manifested as horizontal white bands on a blue background.

2.12 Intracellular ROS formation. ROS generation was detected by NBT assay [24]. NBT $(1 \mathrm{mg} / \mathrm{ml}$ ) was added to medium of treated $\mathrm{PC} \mathrm{Cl} 3$ and incubations were carried out at $37^{\circ} \mathrm{C}$ for $15-60 \mathrm{~min}$. Cells were then carefully washed and lysed in buffer containing $90 \%$ dimethylsulfoxide, $0.01 \mathrm{~N} \mathrm{NaOH}$, and $0.1 \%$ SDS. Absorbance of NBT reduction product formazan was measured at $715 \mathrm{~nm}$ against lysis buffer blank. Data are expressed as \% of control PC Cl3 cell not treated.

2.13 Statistical analysis. Experimental points represent means \pm standard deviation (SD) of 3-6 replicates. Statistical analysis was carried out using the ANOVA. When indicated, post hoc tests (Bonferroni/Dunn) were also performed. A $P$ value less than 0.05 was considered to achieve statistical significance. 


\section{RESULTS}

\subsection{Cisplatin activates EGFR pathway in PC Cl3}

We showed previously that in PC Cl3 cells cisplatin activates ERK which has a protective role [17]. Because cisplatin treatment can activate EGFR upstream to ERK [4], we determined the role of this receptor in the survival of $\mathrm{PC} \mathrm{Cl3}$ cells treated with cisplatin. Indeed, $\mathrm{PC} \mathrm{Cl} 3$ cells treated with cisplatin showed the activation (phosphorylation) of EGFR (Fig. 1A). Furthermore, a membrane translocation of EGFR was also detected in western blot experiments (Fig. 1B), in agreement with data published by others [8]. EGFR translocation was completely blocked by pre-incubation with the specific EGFR inhibitor AG1478 ([25]; $30 \mu \mathrm{M}, 1 \mathrm{~h}$ before cisplatin treatment) (Fig. 1B). Interestingly, the use of 30 $\mu \mathrm{M}$ AG1478 did not inhibit the cisplatin-provoked ERK phosphorylation (Fig. 3).

\subsection{Effects of inhibition of EGFR on cisplatin-induced apoptosis}

To determine whether activated EGFR pathway affects drug sensitivity, PC Cl3 cells were exposed to increasing concentration of cisplatin for 12,24 and 48 hours in the absence or presence of AG1478. The viable cell number was determined by MTT colorimetrical assay and confirmed by SRB assay to rule out potential effects of cisplatin on mitochondrial enzymes. Indeed, comparable results were obtained when cell number was directly determined by cell counting; consequently, we used the MTT assay in the all the cytotoxicity experiments described herein. Treatment of thyroid cells with cisplatin induced cell death with the morphological characteristics of apoptosis, including nuclear condensation and DNA fragmentation, as well as caspases activation. Apoptotic morphology was detectable 24-72 h after treatment, with a maximum after $48 \mathrm{~h}$ [18]. Preincubation of PC Cl3 cells with AG1478 (15-30 $\mu \mathrm{M})$ increased resistance to cisplatin (Fig. 2; $\mathrm{p}<0.001$ ). As shown in Fig. $2 \mathrm{C}$, after $24 \mathrm{~h}$ of $100 \mu \mathrm{M}$ cisplatin treatment, approximately $50 \%$ and $78 \%$ of untreated and AG1478-treated PC Cl3 cells, respectively, had survived. Inhibition of EGFR by AG1478 significantly improved PC Cl3 cells morphology after cisplatin treatment. DAPI analysis demonstrated that the percentage of cisplatin-induced apoptotic cells (45.3\%) was significantly decreased in AG1478 pre-treated (22.15\%) (Table 1).

Then, we determined the role of EGFR pathway in cisplatin-induced PC Cl3 cell death. As shown in Fig. 3, cisplatin-induced PARP cleavage was partially inhibited by AG1478 pretreatment. Sequential incubation of the nitrocellulose membrane with anti-actin antibody confirmed the equal protein loading. Similarly, the activation of caspases by treatment with 
cisplatin and AG1478 was qualitatively monitored by measuring the levels of the precursors of caspase 3 and caspase 7 and their relative active forms. AG1478 pretreatment completely inhibited the cisplatin-provoked caspase-7 activation and slightly reduced the effect of cisplatin on caspase-3 (Fig. 3). To provide conclusive evidence of the involvement of the EGFR in cisplatin-induced apoptosis, siRNA-mediated EGFR knockdown was performed. The efficacy of EGFR knockdown was verified by immunoblot analysis (Fig. 7, upper part). Pre-treatment with siRNA-EGFR significantly improved cell morphology (Table 1), decreased apoptotic cells, inhibited caspase-7 and also decreased PARP activations $24 \mathrm{~h}$ after cisplatin treatment (Fig. 3).

\subsection{Cisplatin-induced phosphorylation of p38/MAPK.}

Activation of EGFR has been implicated in the activation of the p38 mitogen-activated protein kinases (MAPK) [26]. Thus, we first investigated whether cisplatin activates the p38 in $\mathrm{PC} \mathrm{Cl} 3$ cells. Using an antibody recognising the dually phosphorylated (threonine 180 and tyrosine 182) $\mathrm{p} 38$, we found that cisplatin provoked its phosphorylation in a timedependent manner (Fig. 4A) without affecting the overall level, detected with an antibody recognising both phosphorylated and un-phosphorylated MAPK (Fig. 4A). Therefore, cisplatin significantly increased the phosphorylation of both MAPKs ERK and p38, with different kinetics. A high level of ERK phosphorylation was already apparent after $2 \mathrm{~h}$ of treatment, whereas p38 phosphorylation was observed later on $(6 \mathrm{~h})$. In both cases an elevated MAPKs phosphorylation was maintained up to $24 \mathrm{~h}$ post-treatment.

\subsection{Effects of p38/MAPK on cisplatin-induced apoptosis}

To test whether the activation of p38/MAPK is required for cisplatin-induced apoptosis, the p38 inhibitor SB203580 [27] was employed to block p38/MAPK kinase activity in cisplatintreated cells. The viable cell number was then determined by MTT and confirmed by SRB methods. Remarkably, SB203580 effectively blocked the cytotoxicity of cisplatin (Fig. 4 BD) and decreased apoptosis (Table 1). These results strongly suggest that p38/MAPK activation is essential for cisplatin-induced apoptosis in $\mathrm{PC} \mathrm{Cl3}$ cells.

\subsection{The mechanism of cisplatin-induced p38/MAPK phosphorylation}

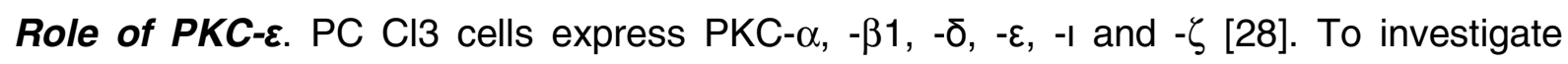
whether or not PKCs were involved in cisplatin-mediated p38/MAPK activation, PC Cl3 cells were pre-incubated for 30 min with the PKC inhibitor GF109203X: Fig. 5A shows that 
the effects of cisplatin on p38/MAPK phosphorylation were completely inhibited at the lowest GF109203X concentration used, indicating a potential involvement of conventional or novel PKCs (GF109203X is also able to inhibit atypical PKCs but at very higher doses [29]). Since the conventional PKCs inhibitor Gö6976 had not effects on p38/MAPK kinase (Fig. 5A), we pointed to novel PKCs. In a previous study, we found that PKC- $\delta$ plays a central role of in the upstream activation of ERK pathway, which is important for maintaining the cell vitality after cisplatin treatment in $\mathrm{PC} \mathrm{Cl3} \mathrm{[18].} \mathrm{Thus,} \mathrm{here} \mathrm{it} \mathrm{seemed}$ appropriate to investigate the role of PKC- $\varepsilon$ on cisplatin-provoked p38/MAPK activation. Since activated PKCs translocate from the cytosol to the cellular membranes, we analysed by western blot the distribution of PKC- $\varepsilon$ in $\mathrm{PC} \mathrm{Cl} 3$ treated with cisplatin $(100 \mu \mathrm{M})$ for different incubation times (1, 3, 6, 12 and 24 h). As shown in Fig. 5B, a cytosol-tomembrane translocation of PKC- $\varepsilon$ was observed. Fig. $5 \mathrm{C}$ shows western blot analyses of homogenates from PC Cl3 cells; cisplatin caused a transient rise in PKC- $\varepsilon$ expression, with maximal increase occurring at $3 \mathrm{~h}$, followed by a progressively decreasing level, and its final cleavage after $24-48 \mathrm{~h}$ of cisplatin treatment. Pre-incubation with AG1478 (30 $\mu \mathrm{M})$ blocked both the cytosol-to-membranes translocation (Fig. 5B) and the cleavage (Fig. 5C) of PKC- $\varepsilon$. Sequential incubation of the membrane with anti-actin antibody confirmed the equal protein loading. Then, we used molecular (PKC- $\varepsilon-s i R N A)$ and pharmacological (the PKC- $\varepsilon$ translocation inhibitor peptide $\varepsilon \mathrm{V} 1$ [30]) techniques in order to specifically inhibit PKC- $\varepsilon$ and establish its role in p38/MAPK control. Preliminary experiments by western blotting demonstrated that PKC- $\varepsilon$-siRNA was able to reduce PKC- $\varepsilon$ expression and that nonspecific siRNA (siRNA-NS) had no silencing effect on PKC- $\varepsilon$ expression at either 24 or $48 \mathrm{~h}$ post transfection (Fig. 5D). The PKC- $\varepsilon$-siRNA (10 nM) inhibited cisplatin-induced p38/MAPK phosphorylation in PC Cl3 cells (Fig. 5E). This result was confirmed by using $100 \mu \mathrm{M} \varepsilon V_{1}$ (Fig. 6A top).

3.5 Role of EGFR activation. Next we examined the relationship between p38/MAPK and EGFR activities. PC Cl3 were exposed to cisplatin in the presence or absence of AG1478 and the phosphorylation of p38/MAPK was followed by immunoblot analysis; the inhibition of EGFR kinase activity blocked cisplatin-provoked p38/MAPK phosphorylation in a dosedependent manner (Fig. 6B top). Co-incubation of cells with $\varepsilon V 1$ and AG1478 had not additive effects on the cisplatin-induced activation of p38/MAPK (Fig. 6C top).

To examine whether cisplatin citotoxicity was restored in p38/MAPK-inhibited PC Cl3, cells were exposed to cisplatin in the presence and absence of $\varepsilon \mathrm{V} 1$ or AG1478 (both able to 
block the cisplatin-provoked p38/MAPK phosphorylation) and viable cell number was assessed after $24 \mathrm{~h}$ treatment. It can be seen that both inhibitors increased viable cells from 50 to 76\% (ANOVA: $\mathrm{p}<0.001$; Fig. $6 \mathrm{~A}$ and $\mathrm{B}$ ). When PC Cl3 cells were preincubated combining $\varepsilon \mathrm{V} 1(100 \mu \mathrm{M})$ and $\mathrm{AG} 1478(30 \mu \mathrm{M})$ no further effects were observed (Fig. 6C).

To explore mechanisms that might contribute to the induction of apoptosis, levels of proapoptotic and anti-apoptotic proteins were measured by Western blot analysis, in whole lysates of cisplatin-treated cells. Thus, cisplatin treatment increased levels of the antiapoptotic protein Bcl-2, without affecting the pro-apoptotic protein Bax (Fig. 7A), indicating the involvement of the intrinsic pathway. Enforced expression of $\mathrm{Bcl}-2$ occurred in $\mathrm{PC} \mathrm{Cl3}$ cells when EGFR and p38/MAPK were inhibited (Fig. 7A). Immunoblot analysis of mitochondrial proteins showed that cisplatin treatment strongly increased Bax level and drastically decreased Bcl-2 level suggesting a shuttle of these proteins between cytosol and mitochondria (Fig. 7B). These translocations were not observed if EGFR and p38/MAPK were inhibited by siRNA-EGFR or by SB203580, respectively (Fig. 7B).

\subsection{Cisplatin regulated MMP-2 activity in PC Cl3 cells}

In order to understand whether MMPs were implicated in cisplatin induced EGF receptor activation, we first assayed the activity of gelatinolytic enzymes in conditioned medium from PC Cl3 cells by gelatin zymography. Indeed, a gelatinolytic activity at around $72 \mathrm{kDa}$ was observed which was considered to correspond to matrix metalloproteinase-2 (MMP2). Cisplatin treatment (100 $\mu \mathrm{M}$ for 3-24 h) progressively increased MMP-2 secretion up to $24 \mathrm{~h}$ (Fig. 8A). Western analyses demonstrated that MMP-2 protein increased after cisplatin treatment in $\mathrm{PC} \mathrm{Cl} 3$ cell lysates, thus confirming that the regulation was at the protein expression level (Fig. 8A). When PC Cl3 cells were pre-incubated with the MMP-2 inhibitor I (20 $\mu \mathrm{M}$ for $30 \mathrm{~min})$ the cell viability assessed after $24 \mathrm{~h}$ of cisplatin treatment increased from 46 to $73 \%$ (ANOVA: $p<0.001$; Fig. 8 C); furthermore, MMP-2 inhibitor I also blocked the activation of caspase-7 (Fig. 8D). Consistent with the hypothesis that MMP-2 participates in EGFR activation, no significant difference in cell viability was observed when $\mathrm{PC} \mathrm{Cl} 3$ cells were pre-incubated simultaneously with MMP-2 inhibitor I and AG1478 (Fig. 8C and table 1). In addition, inhibition of MMP-2 prevented cisplatin-induced p38/MAPK phosphorylation (Fig. 8B). Collectively these results demonstrate that MMP-2EGFR activated signaling regulates cisplatin-provokated PC Cl3 cell apoptosis. 


\subsection{ROS are responsible for the induction of MMP-2 and EGFR transactivation}

To examine whether ROS affected secretion and expression of MMP-2, we first determined the main source of $\mathrm{ROS}$ in $\mathrm{PC} \mathrm{Cl} 3$ treated with cisplatin. ROS production increased during cisplatin treatment and was markedly suppressed by both structurally unrelated inhibitors of NADPH oxidase, diphenyleneiodonium (DPI) and apocynin (Fig. 9A). DPI and apocynin also suppressed cisplatin-induced secretion of MMP-2 (Fig. 9B), and the cisplatin-induced activation of p38/MAPK and caspase-7 (Fig. 9B); consistently, DPI and apocynin decreased cisplatin-induced intrinsic pathway activation (Fig. 9D) and cell death (Table 1). These observations indicate that some ROS-mediated event leads to caspase-7 activation and apoptotic cell death induced by cisplatin through MMP-2 activity. Finally, we determined the influence of ROS generation on EGFR activation by monitoring the phosphorylation of EGFR induced by cisplatin in $\mathrm{PC} \mathrm{Cl3}$ cells pretreated with $\mathrm{DPI}$ or apocynin. As shown in Fig. 9C, both NADPH oxidase inhibitors were able to block the cisplatin-induced phosphorylation of EGFR. 


\section{Discussion}

Cisplatin is an efficient DNA-damaging antitumor agent employed for the treatment of various human cancers. Unfortunately, cisplatin induces many side-effects and its cytotoxicity may disrupt hypothalamic, pituitary, or thyroid function in a variety of ways [31]. The correlation of hypothyroidism and the cumulative doses of cisplatin implicates this drug in the causation [32]. Furthermore, the molecular mechanism to induce growth arrest and/or apoptosis in the normal thyroid cells is still unknown. Cisplatin activates nuclear as well as cytoplasmatic signalling pathways involved in regulation of the cell cycle, damage repair and programmed cell death. In previous studies, we demonstrated that in fully differentiated PC Cl3 thyroid cells cisplatin activated MAPK/ERK which behaved as a prosurvival pathway [17]; here we report that cisplatin also activates a membraneintegrated protein, the epidermal growth factor receptor (EGFR). EGFR plays an important role in the flow of information from the outside of a cell to the inside. Aberrant regulation of EGFR signalling has been implicated in the pathogenesis and progression of many types of cancer. In the normal thyroid gland, EGFR expression is detectable albeit at a low level [33], but its expression is significantly higher in thyroid carcinoma cell lines [33] and it is over expressed in up to $90 \%$ of follicular and papillary thyroid carcinoma specimens [34]. The therapeutic potential of EGFR inhibition in thyroid carcinoma has been shown in several in vitro studies [35-36]. The EGFR can be activated by different stimuli through diverse mechanisms; non-specific stimuli such as osmotic stress, ultraviolet light, oxidative stress, hypoxia/reoxygenation injury, and also cisplatin, trigger EGFR autophosphorylation [4,37,38]. Autophosphorylation of tyrosine 992 and 1173 are critical to EGFR signalling. Phosphorylation at tyrosine 992 creates a direct binding site for phospholipase C- $\gamma$, which results in the activation of PKCs and the subsequent activation of downstream signalling cascades. Using a specific antibody, we demonstrated that in $\mathrm{PC} \mathrm{Cl} 3$, cisplatin induces the phosphorylation of EGFR at tyrosine 1173, that changes cellular localization of receptors due to rapid endocytosis (Fig. 1), as occurs in several cancer cell lines $[8,37]$. The inhibition of EGFR tyrosine kinase achieved by using the AG1478 inhibitor blocks EGFR internalization (Fig. 1) and improved significantly cell survival attenuating the apoptosis provoked by cisplatin (Fig. 2). Consistent with our results are reports that link EGFR activation (by growth factors or cisplatin) with the induction of apoptosis in other cell types $[39,40]$. Caspase-7 activation plays an important role in the induction of apoptosis by EGFR activation in PC Cl3 cells (Fig. 3); similary, in breast cancer cells heregulin-induced apoptosis in the signalling network of EGFR, involves activation of caspase-7 and 
degradation of PARP [40]. Although the induction of apoptosis is clearly a very complex process that involves several factors and signal pathways, this study supports the involvement of the intrinsic pathway, characterized by $\mathrm{Bcl}-2$ down regulation and Bax translocation to the mitochondria (Fig. 7).

Although it has been reported that cisplatin provokes EGFR internalization mediated by p38/MAPK phosphorylation [8,37], we found that inhibition of EGFR tyrosine kinase prevented cisplatin-induced p38/MAPK activation (Fig. 6) without affecting cisplatininduced ERK activation (Fig. 3). These MAPK pathways are structurally related but biochemically and functionally distinct. Whereas ERK activation, as previously demonstrated [17,18], confers survival advantage to $\mathrm{PC} \mathrm{Cl3}$ cells, the inhibition of p38/MAPK activity decreased cisplatin-induced apoptosis (Fig. 4). Thus, our results and the data reported by others [41] support the notion that p38/MAPK activation is a critical step in cisplatin-induced apoptosis. There is conflicting evidence for the role of p38/MAPK in influencing cell survival of cisplatin-treated cells. For example, studies have suggested that over expressing an active form of the p38/MAPK activator MKK6 protects cardiac myocytes from treatment with anisomyc [42]. Similarly, early activation of p38/MAPK is necessary and sufficient to protect Kym cells from tumour necrosis factor- $\alpha$-mediated apoptosis [43], and expression of the p38/MAPK attenuates cell death induced by Fas ligand and UV light [44]. There are even more reports concerning a proapoptotic function of p38/MAPK: it is proapoptotic in apoptosis induced by withdrawal of trophic factors [45], glutamate [46], and sodium salicylate [47]. Such opposite effects on apoptosis are not unique to p38/MAPK. Many growth-promoting pathways can be either pro- or antiapoptotic, depending on the cellular context [48]. The exact position of p38/MAPK activation in the chain of signalling pathways from EGFR leading to the execution of cell death program is still undetermined; however, it is clear that activation of p38/MAPK kinase is an event mediated by PKC- $\varepsilon$, since its inhibition (by siRNA-PKC- $\varepsilon$ or $\varepsilon V 1$ inhibitor) blocks p38/MAPK activation (Fig. 5) and significantly increased the cellular resistance to cisplatin (Fig. 6). In PC Cl3, cisplatin was able to induce both a cytosol-tomembrane translocation and a proteolytic activation of PKC- $\varepsilon$, both blocked by EGFR pathway inhibition (Fig. 5). Also for PKC- $\varepsilon$, there is conflicting evidence as regards its role: activation of PKC- $\varepsilon$ may have a pro-apoptotic or anti-apoptotic effect which is presumably dependent on cell type or apoptosis inducing agent. PKC- $\varepsilon$ acts a protective role against oxidative stress-induced injury in diverse cell types [49], for example, inhibiting mitochondrial permeability transition pore opening, which prevents apoptosis [50]. Over 
expression of PKC- $\varepsilon$ in MCF-7 cells inhibited TNF-induced apoptosis and proteolytic cleavage prevented its antiapoptotic signal [51]. A down-regulation of PKC.- $\varepsilon$ by chronic exposure to a phorbol ester was associated with resistance to drug-induced apoptosis in human prostatic carcinoma cells [52]. However, consistently with our results, there is also evidence that suggest a pro-apoptotic role of PKC- $\varepsilon$. In fact, in SKBR-3 human breast carcinoma cell lines, antisense oligonucleotides against $\mathrm{PKC}-\varepsilon$ reduced cisplatin cytotoxicity [53]. In NIH3T3 cells PKC- $\varepsilon$-mediated ERK1/2 activation was responsible for the radiation- [54], and cisplatin- induced cell death. However, the role for PKC- $\varepsilon$ in $\mathrm{PC} \mathrm{Cl3}$ apoptosis-signaling pathways, caused by many stimuli, such as growth factor or TSH deprivation, protein synthesis inhibitors, UV radiation, ceramide and a lipid second message commonly generated after DNA damage, was already well known [55]; but here for first time, we described its linkage with p38/MAPK mediated-apoptosis. An alternative mechanism to p38/MAPK, for EGFR transactivation, is the autocrine/paracrine release of soluble EGF ligands [56]. HB-EGF, epiregulin, and TGF- $\alpha$ can activate EGFR; these ligands are synthesized as transmembrane proteins (proforms) and cleaved by metalloproteases to yield soluble forms, thereby binding and leading to EGFR activation $[13,14]$. Indeed, we detected a baseline MMP-2 activity in conditioned media from PC Cl3 cells, and such activity, and MMP-2 protein expression, increased in a time-dependent manner after cisplatin treatment (Fig. 8). MMP-2 inhibition affected cisplatin sensitivity, with an increase of cell survival and prevented the cisplatin-stimulated p38/MAPK activation and caspase-7 proteolysis, suggesting the role of MMP-2 in activating cell death pathway (Fig. 8). In addition, since combination of MMP-2 inhibitor and down regulation of EGFR (by siRNA) did not result in synergistic effect on cell survival and on inhibition caspase-7 proteolysis (Fig. 8), it is clear that MMP-2 and EGFR mediate their physiological responses using overlapping pathways. But the signalling mechanisms by which cisplatin stimulation modulated MMP-2 expression in thyroid cells are not yet clear. Several studies suggest that reactive oxygen species (ROS) play a major role in the activation of MMPs [57,58], and that $\operatorname{NAD}(\mathrm{P}) \mathrm{H}$ oxidase activation, a major source of ROS, is a key event in this process [59]. We here show that the inhibition of $\mathrm{NAD}(\mathrm{P}) \mathrm{H}$ oxidase not only prevented cisplatin-induced ROS generation and increase of MMP-2, but also inhibited p38/MAPK and EGFR activation, caspase-7 proteolysis and the arise of the apoptotic intrinsic pathway (Fig. 9). Obviously, this leads to a decrease of cisplatin-induced cell death. Thus, this study provides compelling data to support a model (oxidant-induced metalloproteasedependent EGFR transactivation) that could identify a relationship between cisplatin and 
EGFR transactivation in inducing cell apoptosis. The key points of this model are summarized in Fig. 10.

Enhanced tumor chemosensitivity may be due, in addition to DNA-damaging effects, also to the internalization of important receptors for growth and survival factors [37]. We propose that removal of EGFR and other receptors from the $\mathrm{PC} \mathrm{Cl} 3$ cell surface helps evade survival signaling (like MAPK and phosphoinositide 3 kinase; PI3K) and enhances cisplatin-induced cell death. When cisplatin treatment is combined with kinase inhibitor, receptors remaining at the cell surface are catalytically inhibited, thereby blocking escape from cell death. Another possibility is that the repression of the EGFR pathway may confer a survival advantage to $\mathrm{PC} \mathrm{Cl} 3$ cells by slowing cell growth and reducing sensitivity to cell cycle-dependent anticancer drug. Small-molecule tyrosine kinase inhibitors, monoclonal antibodies to EGFR or pan-EGFR inhibitors are safe and well tolerated by patients with cancer [60]. Thus, targeting EGFR could be a useful measure in preventing cisplatininduced normal thyroid cell death, in addition to the treatment of cancer. These EGFRmodulated biochemical/molecular events necessary for the cellular response to cisplatin are currently in progress in PC Cl3-derived cells (tumourigenic PC E1Araf cells) transformed by a combination of the adenovirus E1A gene and the raf oncogene [19]. In preliminary experiments, the EGFR-tyrosine kinase inhibition caused an enhancement of the cisplatin cytotoxicy in these cells (Muscella: unpublished data). However these attractive results will require further study. In conclusion, our in vitro studies have shown that elimination of EGFR signalling in normal thyroid cells results in the decrease of the sensitivity to the drug. Conversely, in tumour cells, an overexpression of growth-regulatory signals frequently occur and blocking of EGFR signalling may lower the threshold for drugmediated programmed cell death. This scenario has significant clinical implications. 


\section{REFERENCES}

[1] Santini F, Bottici V, Elisei R, Montanelli L, Mazzeo S, Basolo F, Pinchera A, Pacini F. Cytotoxic effects of carboplatinum and epirubicin in the setting of an elevated serum thyrotropin for advanced poorly differentiated thyroid cancer. J Clin Endocrinol Metab 2002;87: 4160-4165.

[2] Stassi G, Todaro M, Zerilli M, Ricci-Vitiani L, Di Liberto D, Patti M, Florena A, Di Gaudio F, Di Gesù G, De Maria R. Thyroid cancer resistance to chemotherapeutic drugs via autocrine production of interleukin-4 and interleukin-10. Cancer Res 2003;63:67846790.

[3] Haddad R, Mahadevan A, Posner MR, Sullivan C. Long term survival with adjuvant carboplatin, paclitaxel, and radiation therapy in anaplastic thyroid cancer. Am J Clin Oncol 2005;28:104-109.

[4] Istvan A, Megyesi JK, Kaneto H, Price PM, Safirstein RL. Cisplatin-induced cell death is EGFR/src/ERK signaling dependent in mouse proximal tubule cells. Am J Physiol Renal Physiol 2004;287:543-549.

[5] Prenzel N, Fischer OM, Streit S, Hart S, Ullrich A. The epidermal growth factor receptor family as a central element for cellular signal transduction and diversification. EndocrineRelated Cancer 2001; 8:11-31

[6] Murakawa T, Tsuda H, Tanimoto T, Tanabe T, Kitahara S, Matsubara O. Expression of KIT, EGFR, HER-2 and tyrosine phosphorylation in undifferentiated thyroid carcinoma: implication for a new therapeutic approach. Pathol Int. 2005;55:757-765.

[7] Bianco R, Gelardi T, Damiano V, Ciardiello F, Tortora G. Rational bases for the development of EGFR inhibitors for cancer treatment. Int J Biochem Cell Biol. 2007; 34:1416-1431. 
[8] Winograd-Katz SE and Levitzki A. Cisplatin induces PKB/Akt activation and p38/MAPK(MAPK) phosphorylation of the EGF receptor. Oncogene. 2006;25:7381-7390.

[9] Xia Z, Dickens M, Raingeaud J, Davis RJ, and Greenberg ME. Opposing effects of ERK and JNK-p38/MAPK MAP kinases on apoptosis. Science 1995;270:1326-1331.

[10] Mendes O, Kim HT, Lungu G, Stoica G, MMP-2 role in breast cancer brain metastasis development and its regulation by TIMP 2 and ERK 1/2. Clin Exp Metastasis. 2007;24:341-351.

[11] Ramer R, Eichele K, Hinz B. Upregulation of tissue inhibitor of matrix metalloproteinase-1 confers the anti-invasive action of cisplatin on human cancer cells. Oncogene. 2007;26:5822-5827.

[12] Cowden Dahl KD, Symowicz J, Ning Y, Gutierrez E, Fishman DA, Adley BP, Sharon Stack M, Hudson LG. Matrix metalloproteinase 9 is a mediator of epidermal growth factor-dependent E-cadherin loss in ovarian carcinoma cells. Cancer Res 2008;68(12):4606-4613.

[13] Hao L, Du M, Lopez-Campistrous A, Fernandez-Patron C. Agonist-induced activation of matrix metalloproteinase-7 promotes vasoconstriction through the epidermal growth factor-receptor pathway. Circ Res. 2004;94:68-76.

[14] Lucchesi PA, Sabri A, Belmadani S, Matrougui K. Involvement of metalloproteinases $2 / 9$ in epidermal growth factor receptor transactivation in pressure-induced myogenic tone in mouse mesenteric resistance arteries. Circulation. 2004;110:3587-3593.

[15] Masuda $H$, Tanaka $T$ and Takahama $U$, Cisplatin generates superoxide anion by interaction with DNA in a cell-free system. Biochem Biophys Res Commun 1994; 203:1175-1180.

[16] Bragado P, Armesilla A, Silva A, Porras A. Apoptosis by cisplatin requires p53 mediated p38/MAPKalpha MAPK activation through ROS generation. Apoptosis. 2007;12:1733-1742. 
Muscella et al. - Role of EGFR in cisplatin-treated cells - 21

[17] Muscella A, Urso L, Calabriso N, Ciccarese A, Migoni D, Fanizzi FP, Di Jeso B, Storelli C, Marsigliante S. Differential response of normal, dedifferentiated and transformed thyroid cell lines to cisplatin treatment. Biochem Pharmacol. 2005; 71:50-60.

[18] Urso L, Muscella A, Calabriso N, Ciccarese A, Fanizzi FP, Migoni D, Di Jeso B, Storelli C, Marsigliante S. Differential functions of PKC-delta and PKC-zeta in cisplatin response of normal and transformed thyroid cells. Biochem Biophys Res Commun. 2005; 337:297-305.

[19] Fusco A, Berlingieri MT, Di Fiore PP, Portella G, Grieco M, Vecchio G. One- and twostep transformations of rat thyroid epithelial cells by retroviral oncogenes. Mol. Cell. Biol. 1987;7:3365-3370.

[20] Berlingieri MT, Santoro M, Battaglia C, Grieco M, Fusco A. The adenovirus E1A gene blocks the differentiation of a thyroid epithelial cell line, however the neoplastic phenotype is achieved only after cooperation with other oncogenes. Oncogene 1993;8:249-255.

[21] Nørby JG. Coupled assay of Na+/K+ATPase activity. In Methods in Enzymology, vol. 156, part P, ed. Colowick SP \& Kaplan NO. New York: Academic Press, 1988. p.116-119.

[22] Kochhar S, Chuard N, Hottinger H. Glutamate 264 modulates the $\mathrm{pH}$ dependence of the NAD(+)-dependent D-lactate dehydrogenase. J Biol Chem. 1992;267:20298-20301.

[23] Skehan P, Storeng R, Scudiero D, Monks A, McMahon J, Vistica D et al. New colorimetric cytotoxicity assay for anticancerdrug screening. J Natl Cancer Inst 1990; 82: 1107-1112.

[24] Oliveira HR, Verlengia R, Carvalho CR, Britto LR, Curi R, Carpinelli AR. Pancreatic beta-cells express phagocyte-like NAD(P)H oxidase. Diabetes. 2003; 52:1457-1563. 
Muscella et al. - Role of EGFR in cisplatin-treated cells - 22

[25] Partik G, Hochegger K, Schorkhuber M, and Marian B. Inhibition of epidermal-growthfactor-receptor-dependent signalling by tyrphostins A25 and AG1478 blocks growth and induces apoptosis in colorectal tumor cells in vitro. J Cancer Res Clin Oncol 1999;125:379-388.

[26] Kanda Y, Mizuno K, Kuroki Y, Watanabe Y. Thrombin-induced p38 mitogen-activated protein kinase activation is mediated by epidermal growth factor receptor transactivation pathway. Br J Pharmacol. 2001;132:1657-1664.

[27] Bain J, Plater L, Elliott M, Shpiro N, Hastie CJ, McLauchlan H, Klevernic I, Arthur JS, Alessi DR, Cohen P. The selectivity of protein kinase inhibitors: a further update. Biochem J. 2007;408:297-315.

[28] Marsigliante S, Mascella A, Elia MG, Greco S, Storelli C. Angiotensin II AT1 receptor stimulates $\mathrm{Na}+-\mathrm{K}+$ ATPase activity through a pathway involving PKC-z in rat thyroid cells. J Physiol. 2003;546:461-470.

[29] Martiny-Baron G, Kazanietz MG, Mischak H, Blumberg PM, Kochs G, Hug H, Marme $D$, Schachtele $C$. Selective inhibition of protein kinase $C$ isozymes by the indolcarbazole Go6976. J Biol Chem 1993;268: 9194-9197.

[30] Yedovitzky M, Mochly-Rosen D, Johnson JA, Gray MO, Ron D, Abramovitch E, Cerasi E, Nesher R. Translocation inhibitors define specificity of protein kinase C isoenzymes in pancreatic beta-cells. J Biol Chem. 1997 Jan 17;272(3):1417-1420.

[31] Yeung SC, Chiu AC, Vassilopoulou-Sellin R, Gagel RF. The endocrine effects of nonhormonal antineoplastic therapy. Endocr Rev. 1998;19:144-172.

[32] Stuart NS, Woodroffe CM, Grundy R, Cullen MH. Long-term toxicity of chemotherapy for testicular cancer-the cost of cure. Br J Cancer 1990;61:479-484.

[33] Kanamori A, Abe $\mathrm{Y}$, Yajima $\mathrm{Y}$, Manabe $\mathrm{Y}$, Ito K. Epidermal growth factor receptors in plasma membranes of normal and diseased human thyroid glands. J Clin Endocrinol Metab 1989;68:899-903 
Muscella et al. - Role of EGFR in cisplatin-treated cells - 23

[34] Gabler B, Aicher T, Heiss P, Senekowitsch-Schmidtke R. Growth inhibition of human papillary thyroid carcinoma cells and multicellular spheroids by anti-EGF-receptor antibody. Anticancer Res 1997;17:3157-3159.

[35] Bergstrom JD, Westermark B, Heldin NE. Epidermal growth factor receptor signalling activates met in human anaplastic thyroid carcinoma cells. Exp Cell Res 2000;259:293299.

[36] Yin F, Giuliano AE, Van Herle AJ. Signal pathways involved in apigenin inhibition of growth and induction of apoptosis of human anaplastic thyroid cancer cells (ARO). Anticancer Res 1999;19:4297-4303.

[37] Zwang $Y$ and Yarden $Y$. p38/MAPK MAP kinase mediates stress-induced internalization of EGFR: implications for cancer chemotherapy. EMBO J. 2006;25:41954206.

[38] Forsyth CB, Banan A, Farhadi A, Fields JZ, Tang Y, Shaikh M, Zhang LJ, Engen PA, Keshavarzian A. Regulation of oxidant-induced intestinal permeability by metalloproteasedependent epidermal growth factor receptor signaling. J Pharmacol Exp Ther. 2007;321:84-97.

[39] Garcia R, Franklin RA, McCubrey JA. Cell death of MCF-7 human breast cancer cells induced by EGFR activation in the absence of other growth factors. Cell Cycle 2006;5:1840-1846.

[40] Le XF, Marcelli M, McWatters A, Nan B, Mills GB, O'Brian CA, Bast RC Jr. Heregulininduced apoptosis is mediated by down-regulation of Bcl-2 and activation of caspase-7 and is potentiated by impairment of protein kinase $\mathrm{C}$ alpha activity. Oncogene. 2001;20:8258-8269.

[41] Brozovic A, Osmak M. Activation of mitogen-activated protein kinases by cisplatin and their role in cisplatin-resistance. Cancer Lett. 2007;251:1-16. 
Muscella et al. - Role of EGFR in cisplatin-treated cells - 24

[42] Zechner D, Craig R, Hanford DS, McDonough PM, Sabbadini RA, Glembotski CC. MKK6 activates myocardial cell NF-kappaB and inhibits apoptosis in a p38/MAPK mitogen-activated protein kinase-dependent manner. J Biol Chem. 1998; 273:8232-8239.

[43] Roulston A, Reinhard C, Amiri P, Williams LT. Early activation of C-Jun N-terminal kinase and p38/MAPK kinase regulate cell survival in response to tumor necrosis factor alpha. J Biol Chem. 1998;273:10232-10239.

[44] Ivanov VN, and Ronai Z. p38/MAPK protects human melanoma cells from UVinduced apoptosis through down-regulation of NF-kappaB activity and Fas expression. Oncogene. 2000;19:3003-3012.

[45] Kummer JL, Rao PK, Heidenreich KA. Apoptosis induced by withdrawal of trophic factors is mediated by p38/MAPK mitogen-activated protein kinase. J Biol Chem. 1997;272:20490-20494.

[46] Kawasaki H, Morooka T, Shimohama S, Kimura J, Hirano T, Gotoh Y, Nishida E. Activation and involvement of p38/MAPK mitogen-activated protein kinase in glutamateinduced apoptosis in rat cerebellar granule cells. J Biol Chem. 1997;272:18518-18521.

[47] Schwenger P, Bellosta P, Vietor I, Basilico C, Skolnik EY, Vilcek J. Sodium salicylate induces apoptosis via p38/MAPK mitogen-activated protein kinase but inhibits tumor necrosis factor-induced c-Jun N-terminal kinase/stress-activated protein kinase activation. Proc Natl Acad Sci USA. 1997;94:2869-2873.

[48] Joneson T, Bar-Sagi D. Suppression of Ras-induced apoptosis by the Rac GTPase. Mol Cell Biol. 1999 Sep;19(9):5892-5901.

[49] Di-Capua N, Sperling O, Zoref-Shani E. Protein kinase C-epsilon is involved in the adenosine-activated signal transduction pathway conferring protection against ischemiareperfusion injury in primary rat neuronal cultures. J Neurochem. 2003;84:409-412 
[50] Baines CP, Song CX, Zheng YT, Wang GW, Zhang J, Wang OL, Guo Y, Bolli R, Cardwell EM, Ping P. Protein kinase Cepsilon interacts with and inhibits the permeability transition pore in cardiac mitochondria. Circ. Res. 2003;92: 873-880.

[51] Basu A, Lu D, Sun B, Moor AN, Akkaraju GR and Huang J. Proteolytic activation of protein kinase $\mathrm{C}$-epsilon by caspase-mediated processing and transduction of antiapoptotic signals. J Biol Chem 2002;277:41850-41856.

[52] Gonzalez-Guerrico AM, Kazanietz MG. Phorbol ester-induced apoptosis in prostate cancer cells via autocrine activation of the extrinsic apoptotic cascade: a key role for protein kinase C delta. J Biol Chem. 2005;280:38982-38991.

[53] Ohmori T, Arteaga CL. Protein kinase $C$ epsilon translocation and phosphorylation by cis-diamminedichloroplatinum(II) (CDDP): potential role in CDDP-mediated cytotoxicity. Cell Growth Differ. 1998;9:345-353.

[54] Lee YJ, Soh JW, Jeoung DI, Cho CK, Jhon GJ, Lee SJ, Lee YS. PKC epsilon mediated ERK1/2 activation involved in radiation-induced cell death in NIH3T3 cells. Biochim Biophys Acta. 2003. 1593(2-3):219-229.

[55] Knauf JA, Elisei R, Mochly-Rosen D, Liron T, Chen XN, Gonsky R, Korenberg JR, Fagin JA. Involvement of protein kinase Cepsilon (PKCepsilon) in thyroid cell death. A truncated chimeric PKCepsilon cloned from a thyroid cancer cell line protects thyroid cells from apoptosis. J Biol Chem. 1999;274:23414-23425.

[56] Carpenter G. Receptors for epidermal growth factor and other polypeptide mitogens. Annu Rev Biochem 1987;56:881-914.

[57] Rajagopalan S, Meng XP, Ramasamy S, Harrison DG, Galis ZS. Reactive oxygen species produced by macrophage-derived foam cells regulate the activity of vascular matrix metalloproteinases in vitro. Implications for atherosclerotic plaque stability. J Clin Invest 1996;98:2572-2579. 
Muscella et al. - Role of EGFR in cisplatin-treated cells - 26

[58] Siwik DA, Pagano PJ, Colucci WS. Oxidative stress regulates collagen synthesis and matrix metalloproteinase activity in cardiac fibroblasts. Am J Physiol Cell Physiol 2001;280:53-59.

[59] Grote K, Flach I, Luchtefeld M, Akin E, Holland S.M, Drexler H, et al. Mechanical stretch enhances mRNA expression and proenzyme release of matrix metalloproteinase-2 (MMP-2) via NAD(P)H oxidase derived reactive oxygen species. Circ Res 2003;92:80-86.

[60] Thomas SM and Grandis JR. Pharmacokinetic and pharmacodynamic properties of EGFR inhibitors under clinical investigation. Cancer Treat Rev 2004;30:255-268. 


\section{Legend to table and figures}

Figure 1 - Cisplatin induces phosphorylation and internalization of EGFR.

(A) Cells were treated with cisplatin for the indicated time intervals and cell lysates were analyzed by western blotting with anti-phosphorylated-EGFR ( $p$-EGFR) and with anti-totalEGFR (unphosphorylated and phosphorylated-EGFR) antibodies. Control loading is shown by $\beta$-actin.

(B) Cells were pre-treated or not with EGFR inhibitor, AG1478, and with cisplatin for the indicated time intervals. Membrane fractions were analyzed by western blotting with antitotal-EGFR (unphosphorylated and phosphorylated-EGFR) antibody. Control loading is shown by alpha subunity of $\mathrm{Na}^{+} / \mathrm{K}^{+} \mathrm{ATPase}$.

Representative immunoblots of three experiments are depicted.

Figure 2 - Effect of EGFR inhibition on cisplatin-induced cytotoxicity.

Cells were pre-treated or not with two different concentration of EGFR inhibitor AG1478, and then with increasing concentrations of cisplatin for the indicated time periods. Viable cell numbers were assessed by a MTT assay as described in Material and Methods. The data are means \pm S.D. of four different experiments run in eight replicate and are presented as percent of control. Values with shared letters are not significantly different according to Bonferroni/Dunn post hoc tests.

Figure 3 - Effects of EGFR inhibition on cisplatin-induced apoptosis.

Cells were pre-treated or not with $30 \mu \mathrm{M}$ EGFR inhibitor AG1478 for $1 \mathrm{~h}$ (Left) or were transfected with EGFR siRNA or control siRNA (NS) (Right) and then incubated with cisplatin for $24 \mathrm{~h}$. On total lysates western blotting was performed with anti-total EGFR, anti-caspase-7, anti-caspase-3 and anti-ERK1/2 antibodies. Nuclear fractions were analyzed by western blotting with anti-PARP polyclonal antibody. The same blots were stripped and reprobed with an anti- $\beta$-actin monoclonal antibody. Representative immunoblots of three experiments are depicted.

Figure 4 - Cisplatin induces p38/MAPK activation.

(A) Cells were treated with cisplatin for the indicated time intervals and cell lysates were analyzed by western blotting with anti-total-p38/MAPK (unphosphorylated and 
phosphorylated-p38/MAPK) and phosphorylated-p38/MAPK antibodies. Control loading is shown by $\beta$-actin. Representative immunoblots of three experiments are depicted.

(B-D) Cells were pre-treated or not with $10 \mu \mathrm{M}$ of SB203580, a p38/MAPK inhibitor, and then with increasing concentrations of cisplatin for the indicated time periods. Viable cell numbers were assessed by a MTT assay as described in Material and Methods. The data are means \pm S.D. of four different experiments run in eight replicate and are presented as percent of control. Asterisks indicate values that are significantly different $(P<0.05)$ from cisplatin alone at the same time point.

\section{Figure 5 - Role of PKC- $\varepsilon$ in cisplatin-induced p38/MAPK activation.}

(A) Cells were pre-treated or not with a PKC inhibitors, GF109203X or Gö6976, and then treated with cisplatin. Cell lysates were analyzed by western blotting with antiunphosphorylated (p38/MAPK) and with phosphorylated-p38/MAPK (p-p38/MAPK) antibodies.

(B and C) Cells were pre-treated or not with $30 \mu \mathrm{M}$ of EGFR inhibitor AG1478 and then treated with cisplatin for the indicated time intervals; whole cell lysates or cell fractions (cytosol, membranes and nuclei for translocation studies) were analyzed by western blotting with specific anti-PKC- $\varepsilon$ antibody.

(D, E) Cells were transfected with siRNA-PKC- $\varepsilon$ or control siRNA (NS) and then were incubated with cisplatin. Total lysates were made and western blotting was performed with specific anti-PKC- $\varepsilon$ (D and $E$, in set) or with anti-unphosphorylated (p38/MAPK) and phosphorylated-p38/MAPK (p-p38/MAPK) antibodies (E). Control loadings are shown by $\beta$-actin. Representative immunoblots of three experiments are depicted.

Figure 6 - Role of PKC- $\varepsilon$ and EGFR in cisplatin-induced p38/MAPK activation and apoptosis.

Cells were pre-treated or not with the PKC- $\varepsilon$ inhibitor $\varepsilon \mathrm{V} 1(10-100 \mu \mathrm{M})(\mathrm{A})$ or with the EGFR inhibitor AG1478 (15-30 $\mu \mathrm{M})(\mathrm{B})$ or with both (C) and then were treated with cisplatin for $24 \mathrm{~h}$. Upper: Cell lysates were analyzed by western blotting with antiunphosphorylated (p38/MAPK) and phosphorylated-p38/MAPK (p-p38/MAPK) antibodies. The same blots were stripped and reprobed with an anti- $\beta$-actin monoclonal antibody. Representative immunoblots of three experiments are depicted. cisPt $=$ cisplatin Down: Viable cell numbers assessed by MTT assay as described in Material and Methods The data are means \pm S.D. of four different experiments run in eight replicate and are 
presented as percent of control. Values with shared letters are not significantly different according to Bonferroni/Dunn post hoc tests.

\section{Figure 7 - Role of EGFR and p38/MAPK in cisplatin-induced apoptosis.}

Cells transfected with siRNA-EGFR or control siRNA (NS) were pre-treated or not with the p38/MAPK inhibitor SB203580 $(10 \mu \mathrm{M})$ for $1 \mathrm{~h}$ and then were treated with cisplatin for 24 h. Cell lysates $(A)$ or mitochondrial fraction $(B)$ were analyzed by western blotting with antiBcl-2 and anti-Bax antibodies. The same blots were stripped and reprobed with anti- $\beta$ actin monoclonal or with anti-porin antibodies. Inset: Cell were pre-treated with $10 \mu \mathrm{M}$ SB203580 or transfected with siRNA-EGFR and cell lysates were analyzed by western blotting with anti-(P o No)EGFR antibody. Representative immunoblots of three experiments are depicted.

Figure 8 - Role of MMP-2 in cisplatin-induced p38/MAPK activation and apoptosis.

Serum-starved thyroid cells were treated with cisplatin for the indicated time intervals. Conditioned media and cell lysates were subjected to gelatin zymography and western blot analysis with anti-MMP-2, respectively $(\mathrm{A})$.

Cells were pretreated with the MMP-2 inhibitor I (MMP-2i), or with the EGFR inhibitor AG1478, or with both inhibitors combined for $1 \mathrm{~h}$. Cells were then treated with cisplatin for $24 \mathrm{~h}$. Cell lysates were analyzed by Western blotting with anti-unphosphorylated (p38/MAPK) and phosphorylated-p38/MAPK (p-p38/MAPK) (B), or with anti-caspase-7 antibodies (D), and viable cell numbers were assessed by a MTT assay as described in Material and Methods (C). The data are means \pm S.D. of four different experiments run in eight replicate and are presented as percent of control. Values with shared letters are not significantly different according to Bonferroni/Dunn post hoc tests. For western blottings, control loadings are shown by $\beta$-actin and representative immunoblots of three experiments are depicted.

\section{Figure 9 - Intracellular ROS generation and apoptosis induced by cisplatin are} prevented by apocynin and DPI.

Cells were preincubated with apocynin or DPI for $1 \mathrm{~h}$ and exposed to cisplatin for $24 \mathrm{~h}$. (A) ROS production was measured by NBT reduction as described in Material and Methods. (B) Conditioned media were subjected to gelatin zymography and cell lysates were analyzed by western blotting with anti-phosphorylated p38/MAPK, or with anti-capase-7. 
(C) Cell lysates were analyzed by western blotting with anti-phosphorylated-EGFR ( $p$ EGFR) antibody. (D) mitochondrial fractions were analyzed by western blotting with antiBcl-2 and anti-Bax antibodies.

The same blots were stripped and reprobed with anti- $\beta$-actin or anti-porin antibodies. Representative immunoblots of three experiments are depicted.

Fig 10 - A proposed model for $\mathrm{PC} \mathrm{Cl} 3$ cell response to cisplatin.

Oxidant stress (1) results in activation of MMP-2 (2). Activated MMP-2 can then cleave membrane ligands to a soluble form able to bind to EGFR. (3) EGFR activation results in downstream PKC- $\varepsilon$ (4) and p38/MAPK activation which increases cisplatin mediatedapoptosis (6) by partially be identified intrinsic pathways.

Table 1 - Modulation of sensitivity to cisplatin by different inhibitors in thyroid PC $\mathrm{Cl} 3$ cell line.

Drug-induced apoptosis was measured by DAPI assay after $24 \mathrm{~h}$ exposure to cisplatin $(100 \mu \mathrm{M})$ in the presence or absence of various inhibitors. Mean \pm S.D. of three independent experiments, and statistical analysis was carried out using the Student's $t$ test between treated respect to control $\left({ }^{*}\right)$ or to cisplatin $(\dagger)$. N.S. $=$ not significantly different. 


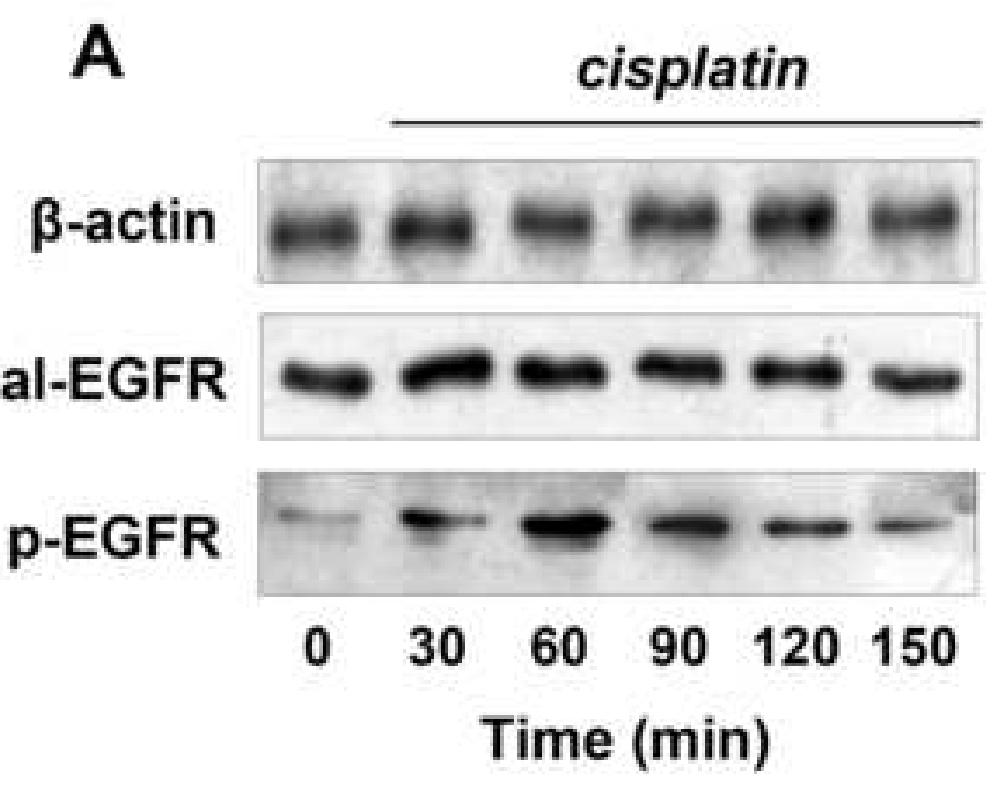

B

cisplatin

total-EGFR

$\alpha-\mathrm{Na}^{+} / \mathrm{K}^{+}$ATPase

FIG. 1 
A

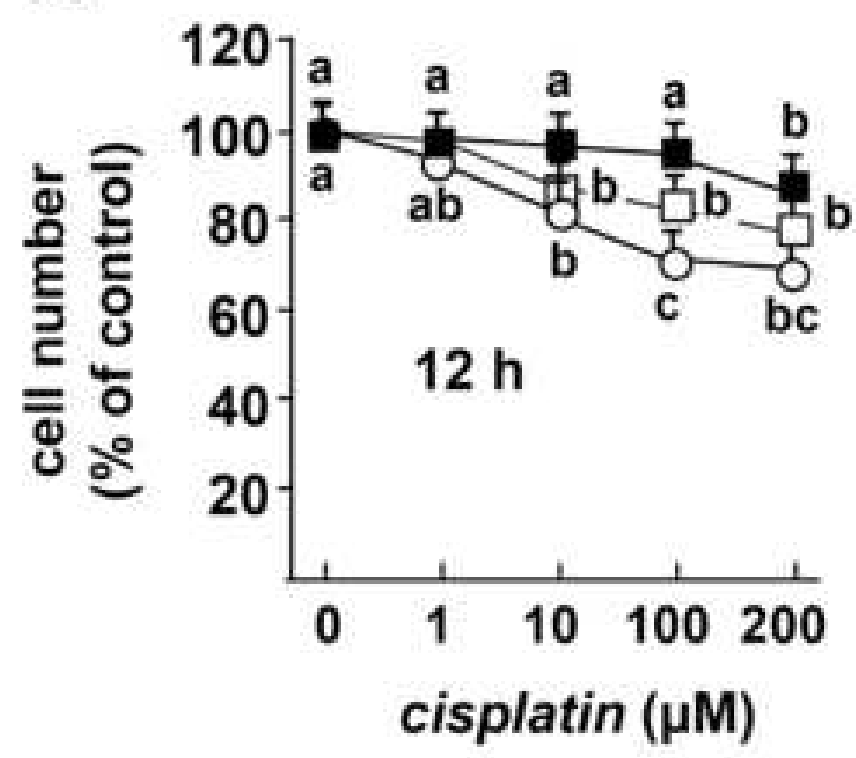

C

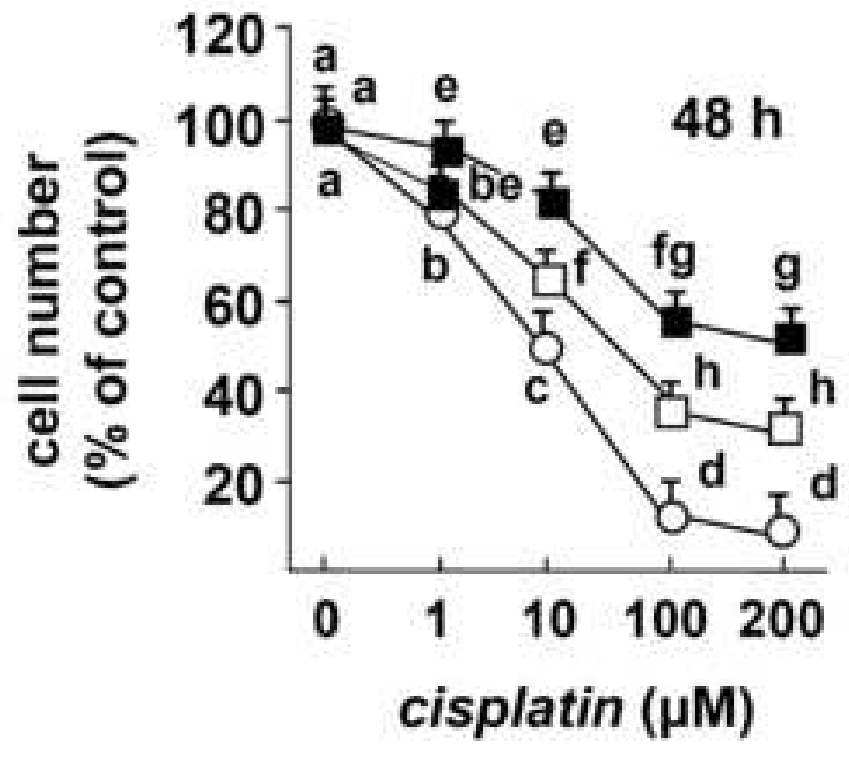

B
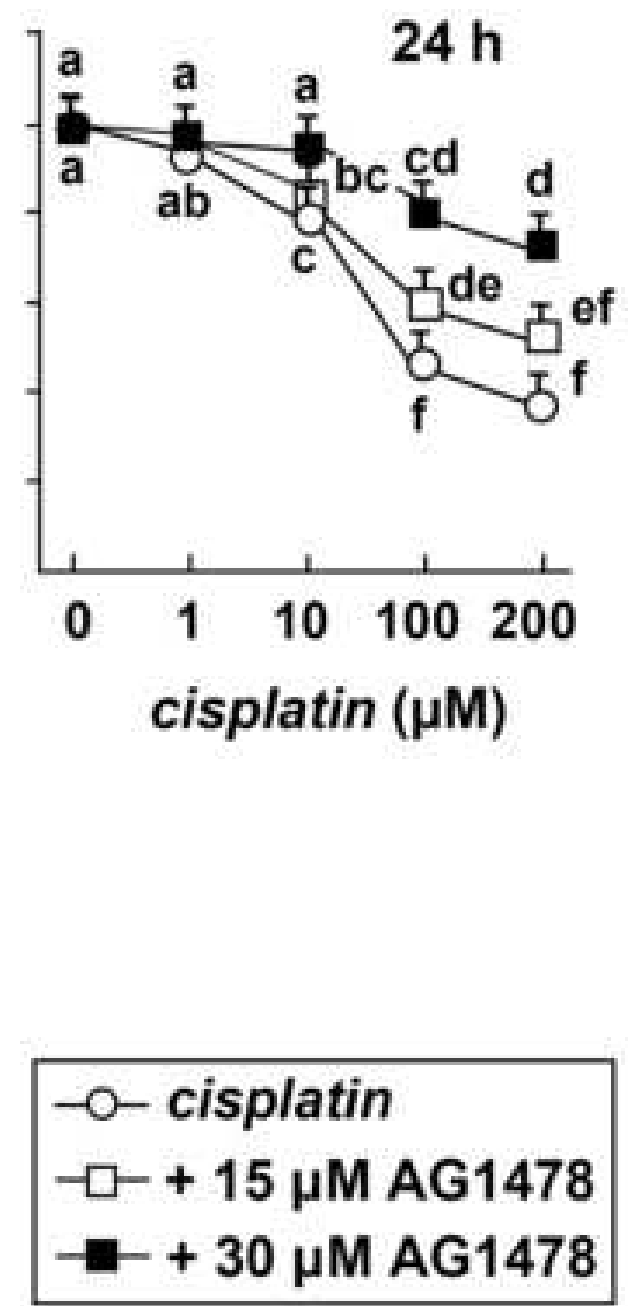
Cisplatin

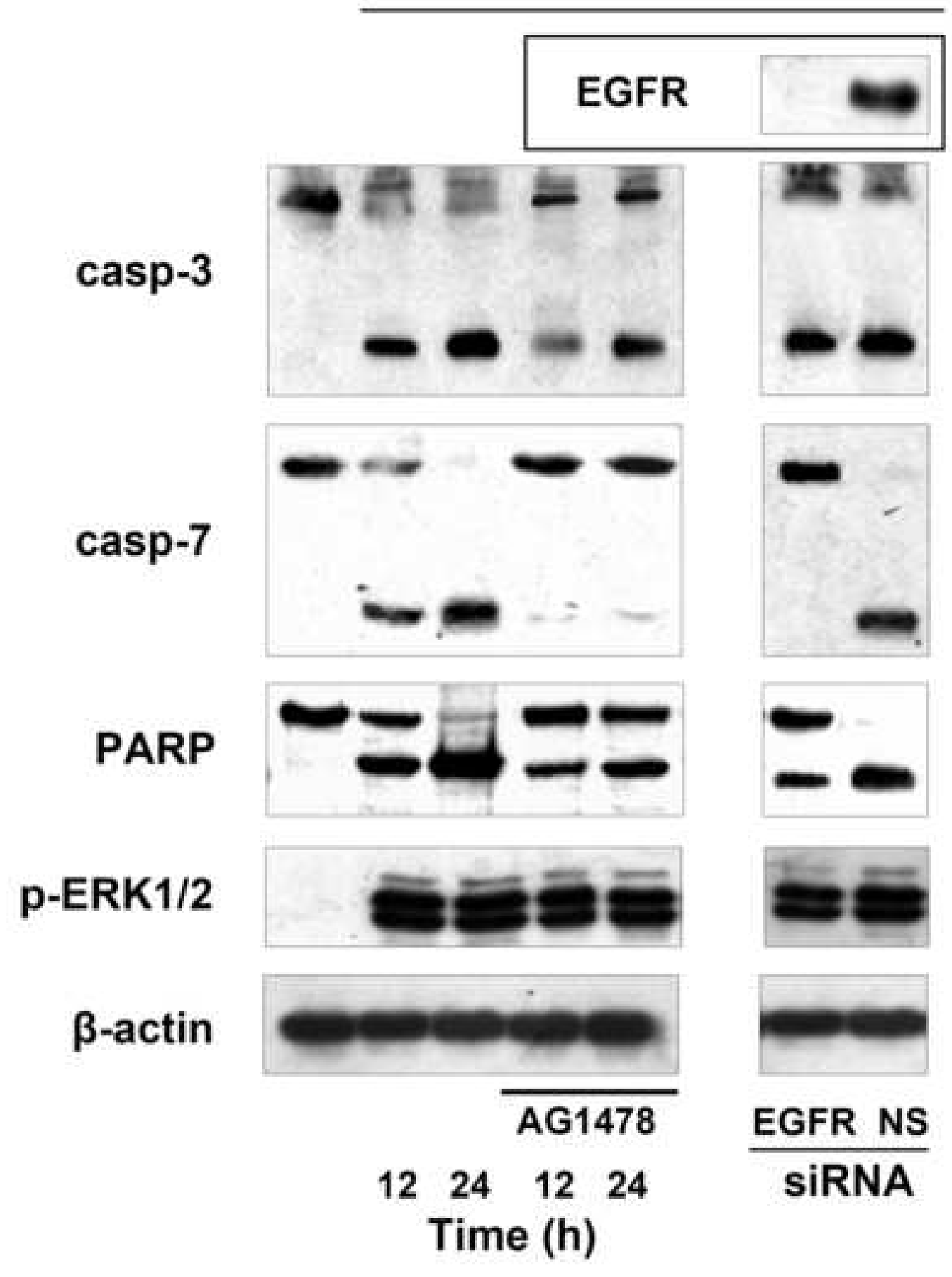

FIG. 3 
A
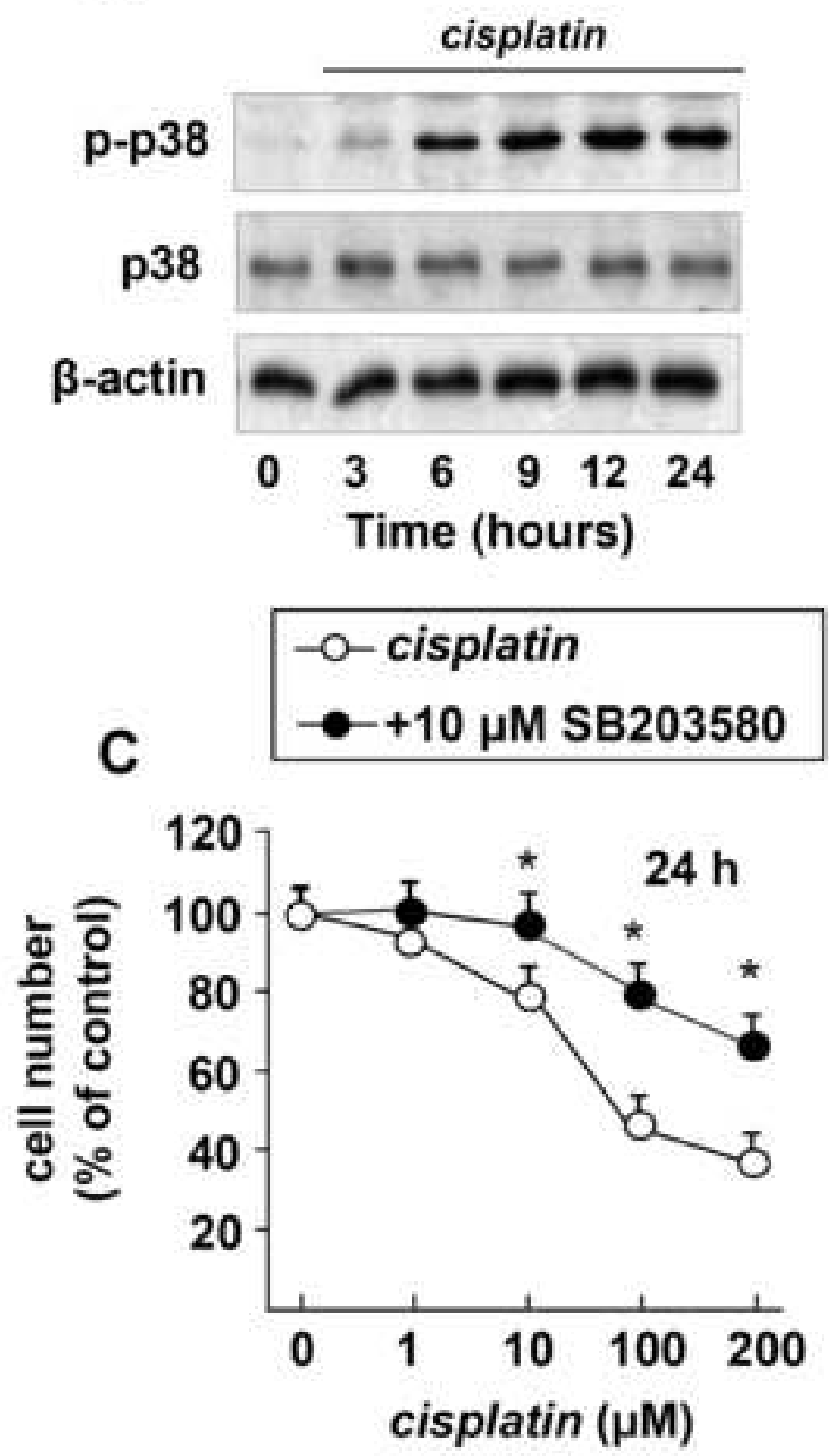

B
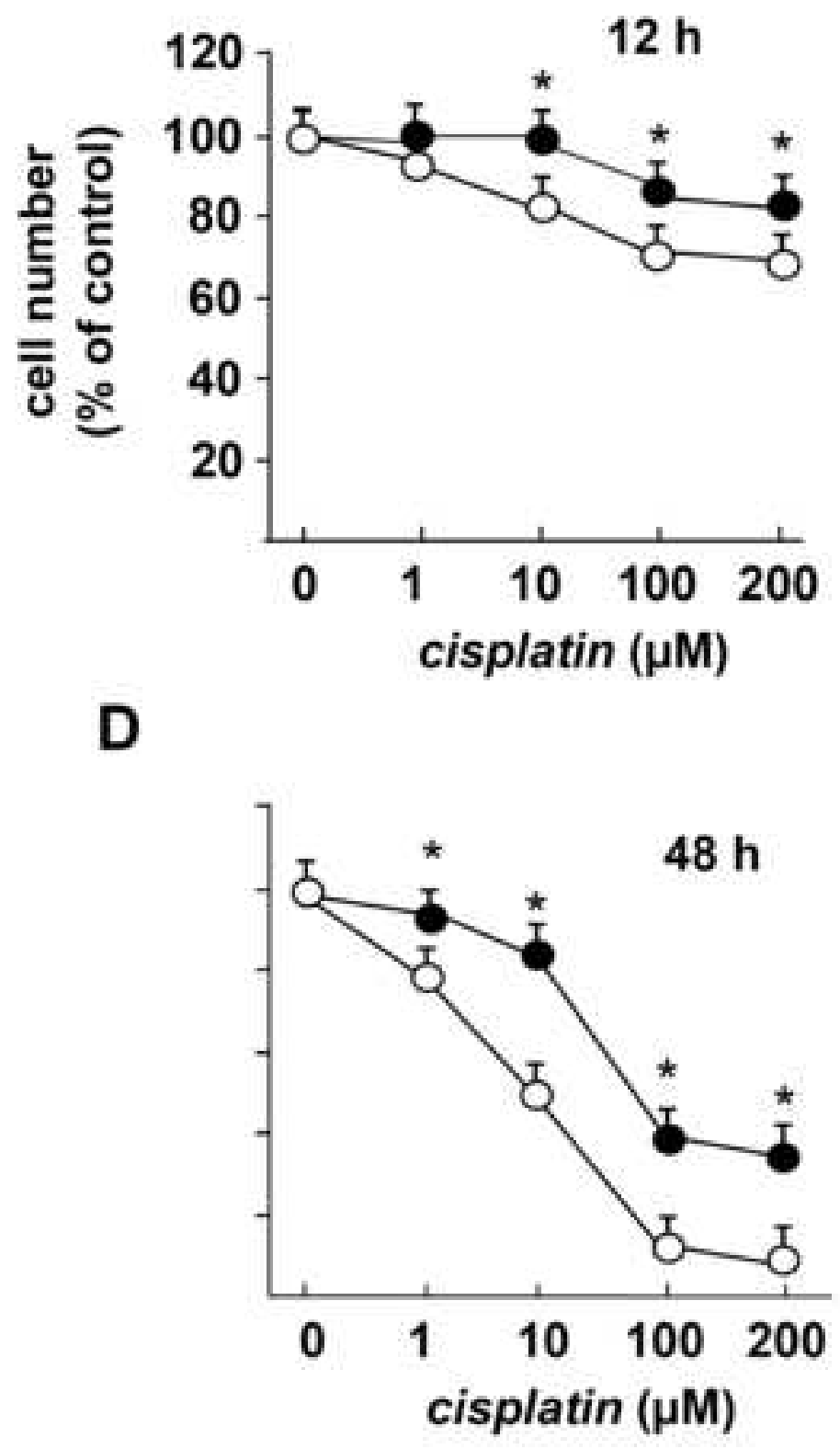

FIG. 4 

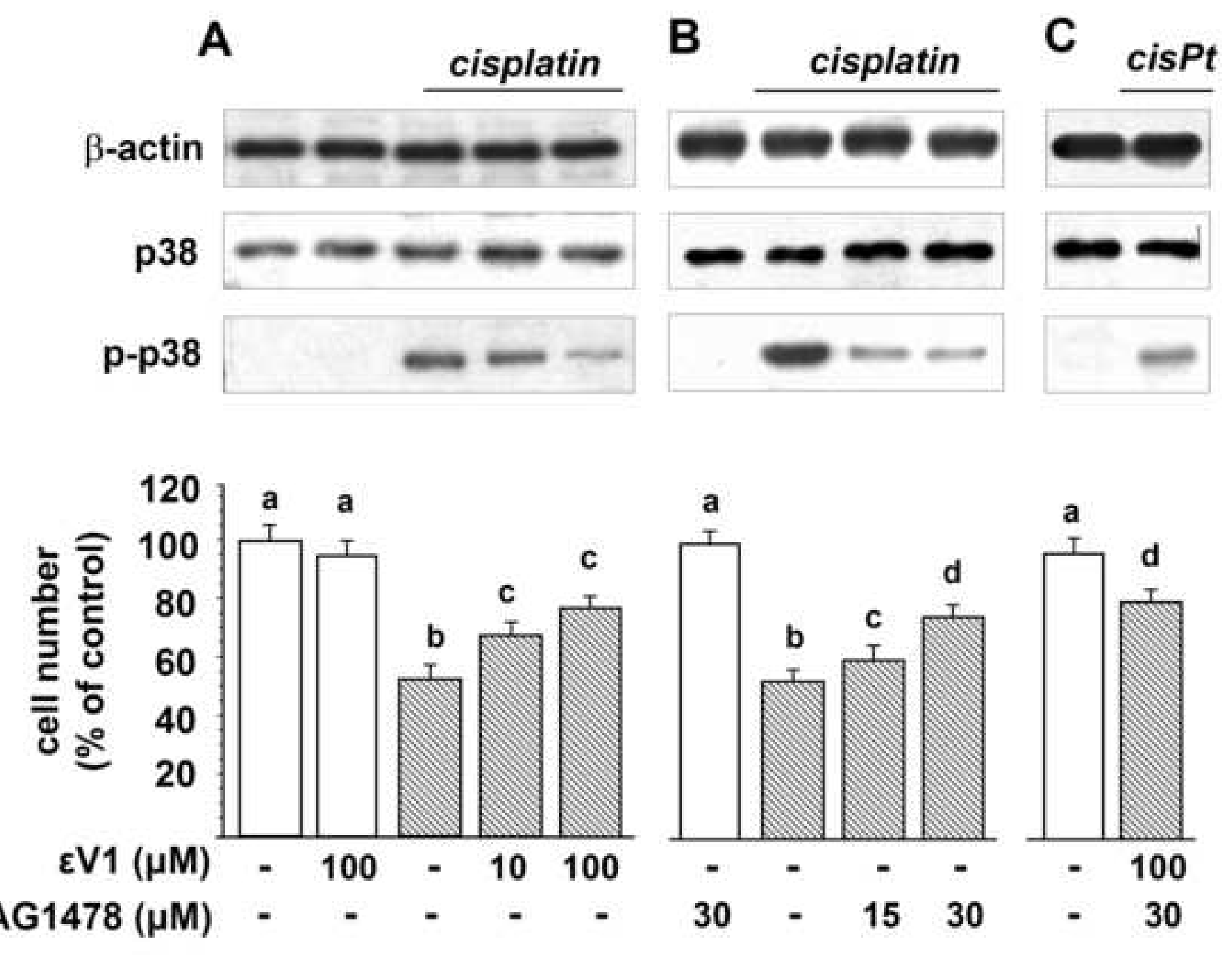

FIG. 6 
A

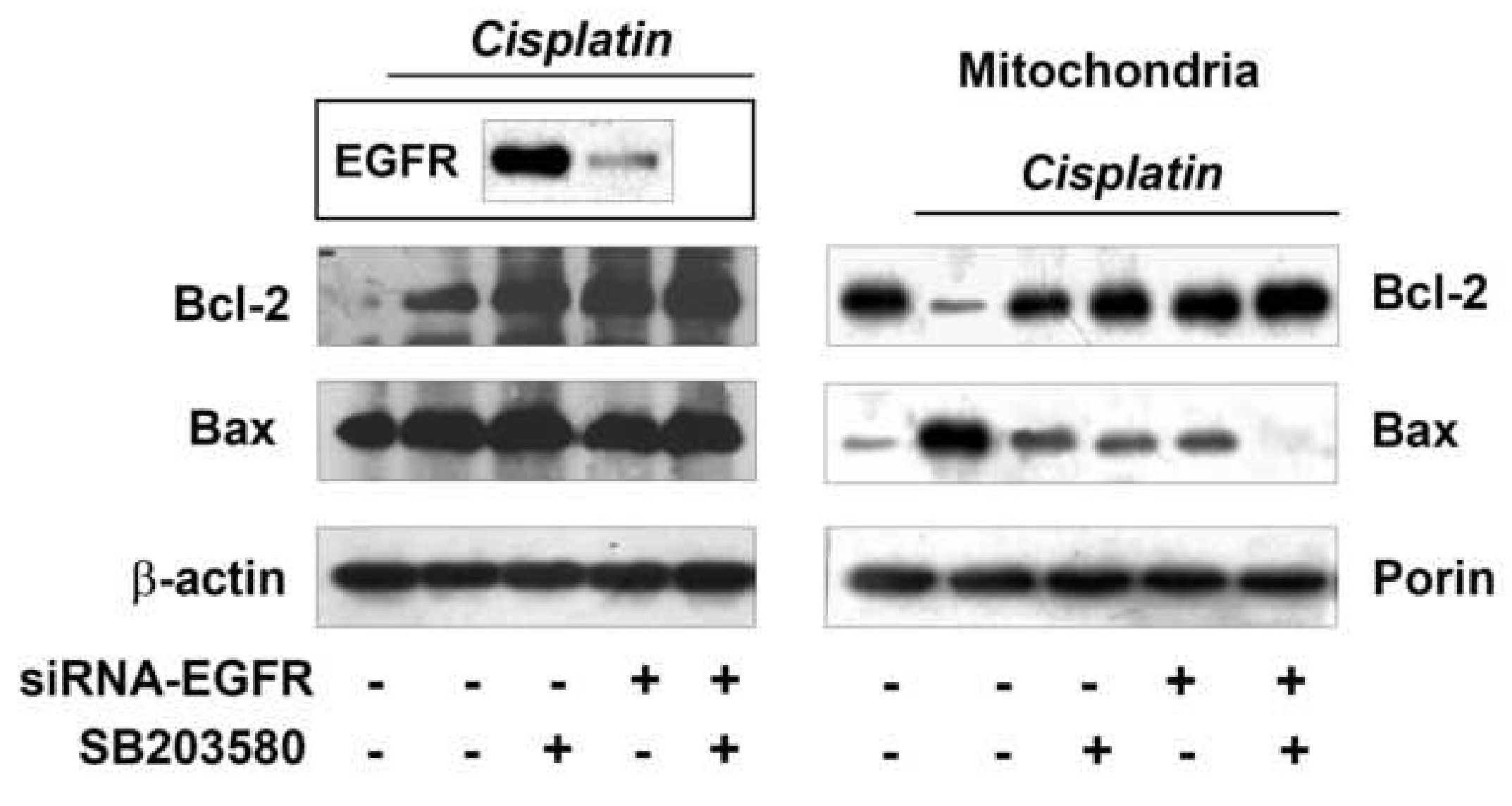


A

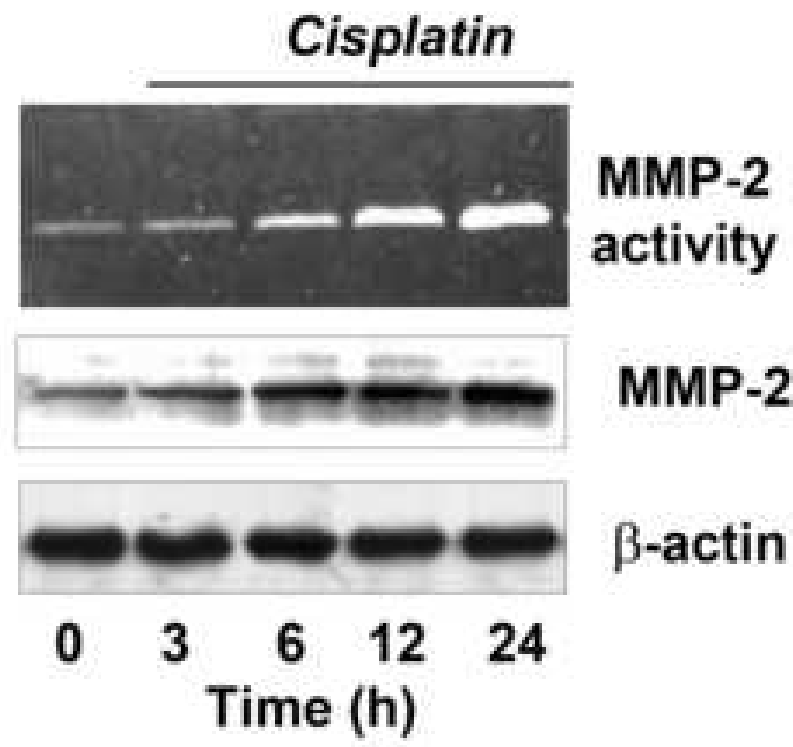

B

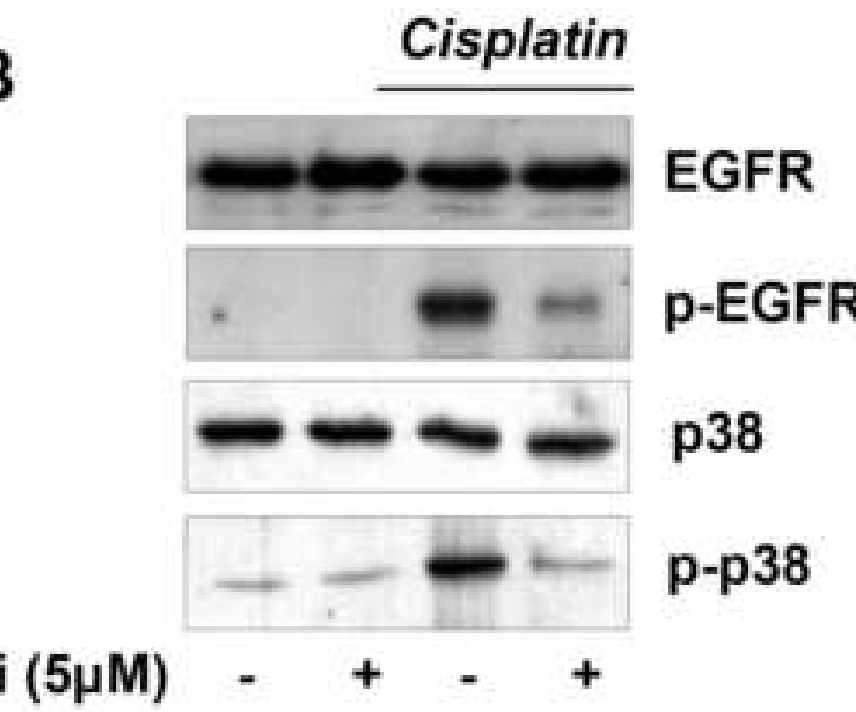

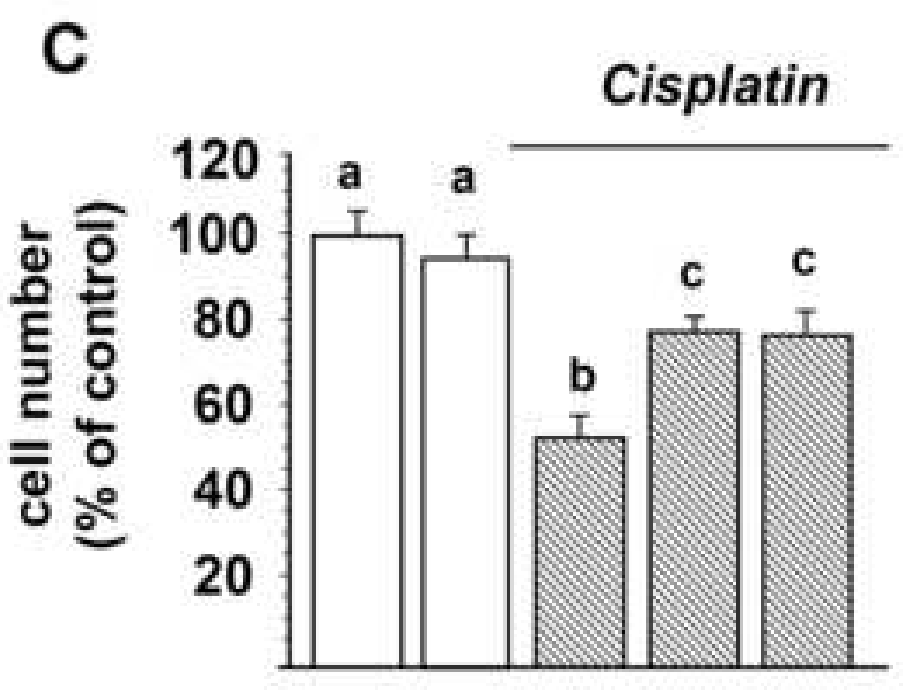

D
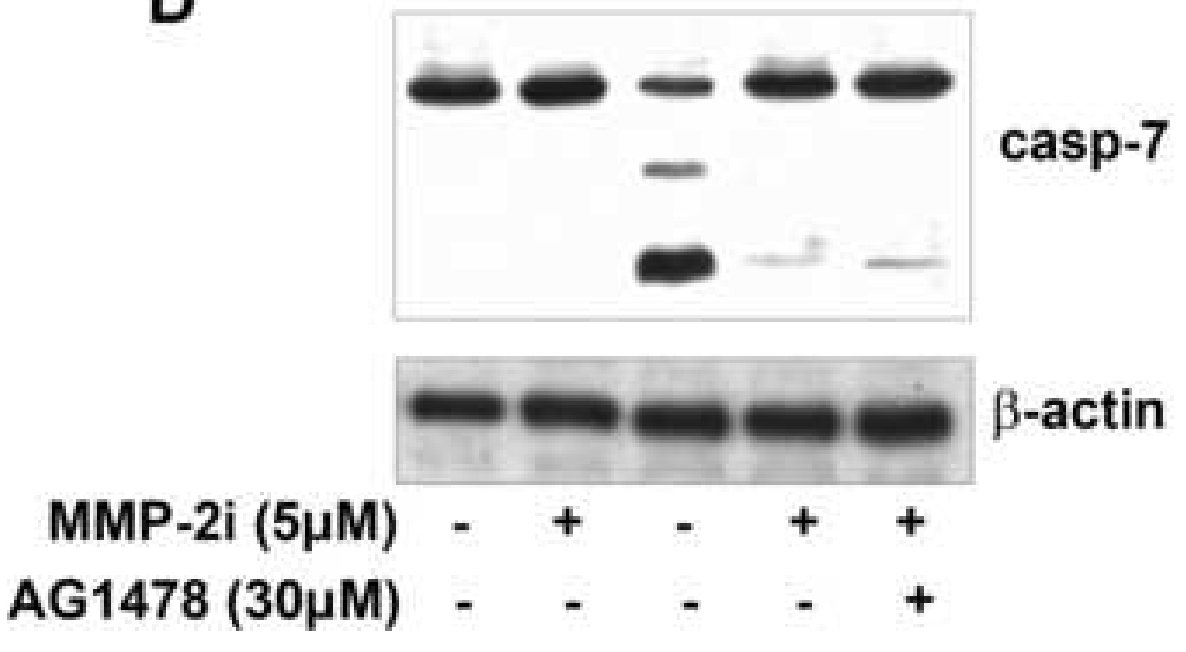

FIG. 8 
A

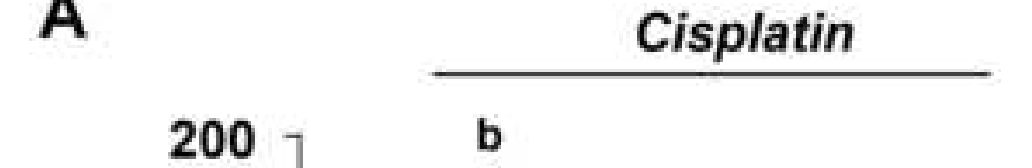

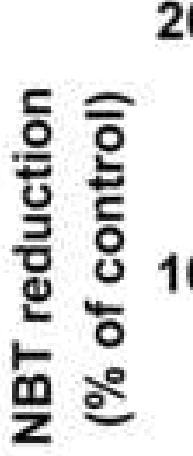

0

B

Apocynin $(\mu \mathrm{g} / \mathrm{ml})$

$$
\mathrm{DPI}(\mu \mathrm{M}) \cdot-\quad-\quad-110
$$

C

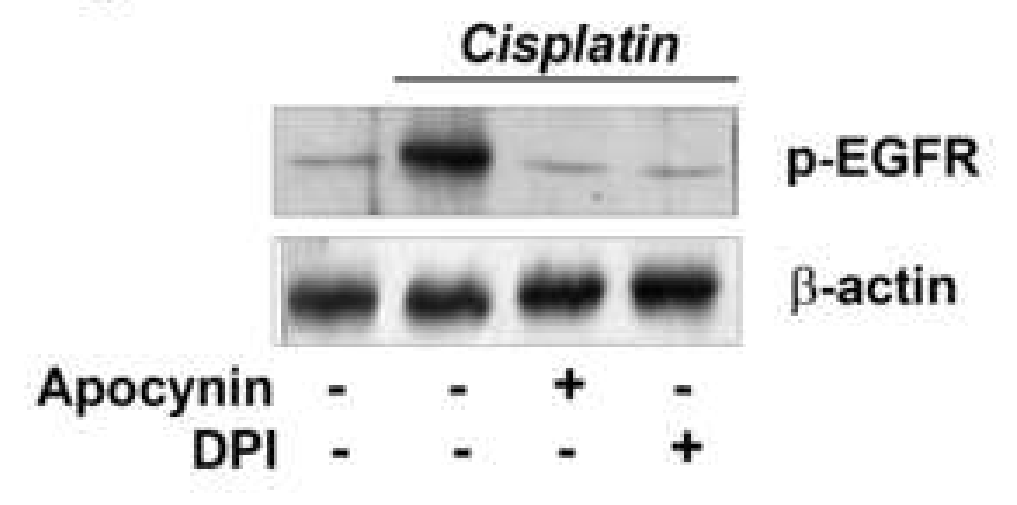

D Mitochondria

MMP-2
activity

p-p38

Cisplatin

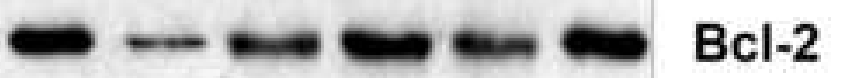

casp-7

$-\mathrm{em}=\mathrm{Bax}$

$\beta$-actin

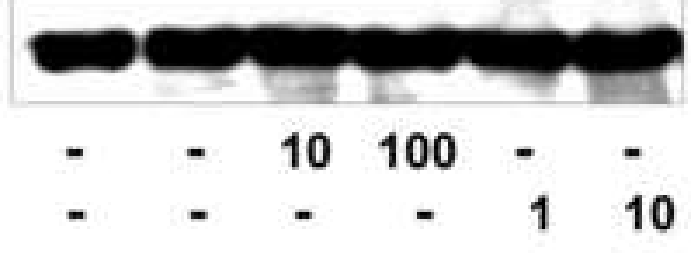

FIG. 9 


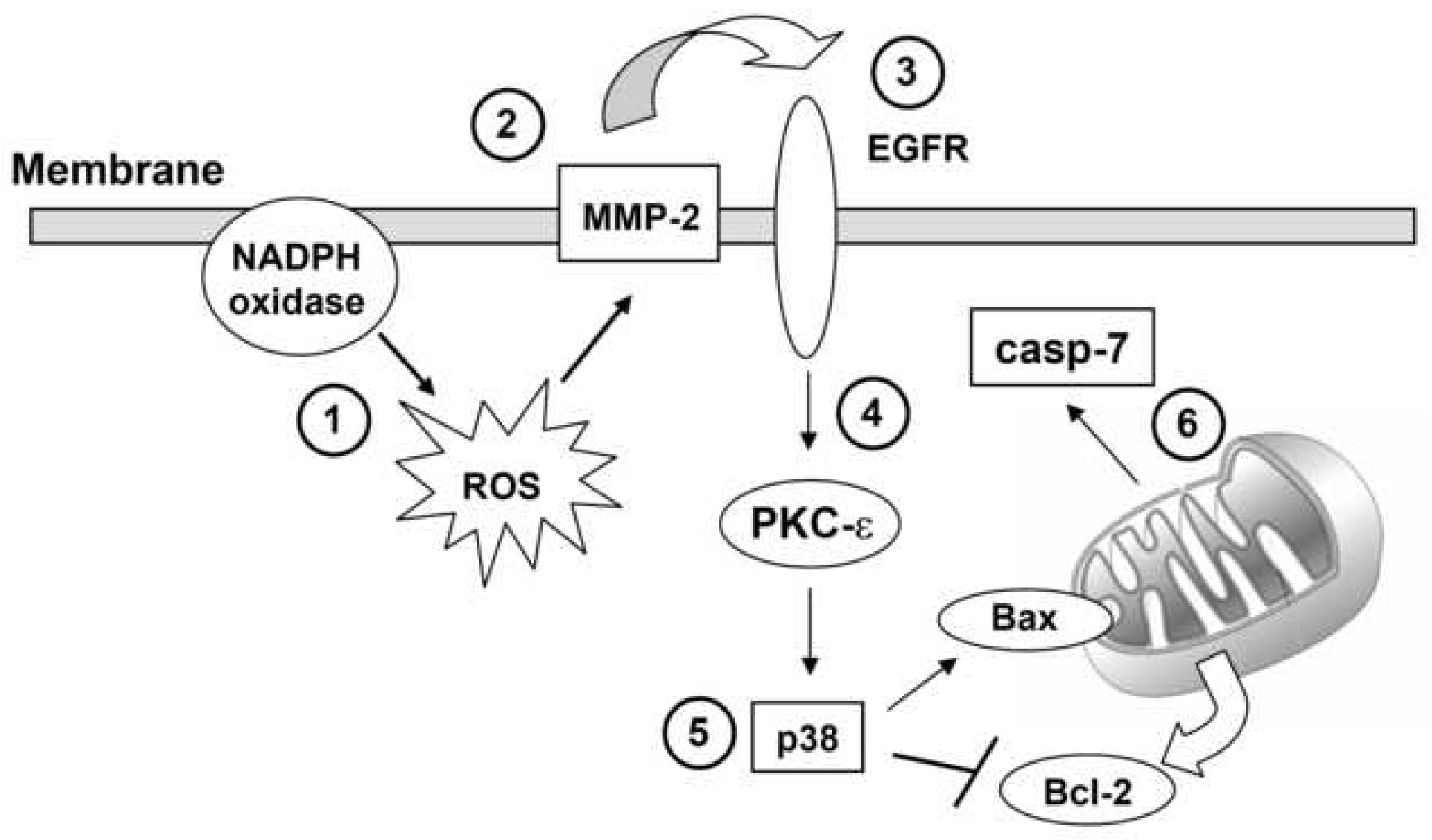

FIG. 10 
Table 1 - Modulation of sensitivity to cisplatin by different inhibitors in thyroid $\mathrm{PC} \mathrm{Cl} 3$ cell line.

\begin{tabular}{|lcc|}
\hline & $\begin{array}{c}\text { Apoptotic cells } \\
(\%)\end{array}$ & P value \\
\hline Control & $2.94 \pm 0.5$ & \\
Cisplatin & $45.34 \pm 5.0$ & $<0.001^{*}$ \\
AG-1478 & $2.86 \pm 0.8$ & N.S. ${ }^{*}$ \\
CisPt + AG-1478 & $22.15 \pm 3.8$ & $<0.001 \dagger$ \\
CisPt + siRNA-EGFR & $23.14 \pm 0.5$ & $<0.001 \dagger$ \\
SB203580 & $3.14 \pm 0.5$ & N.S. ${ }^{*}$ \\
CisPt + SB203580 & $22.55 \pm 3.8$ & $<0.001 \dagger$ \\
CisPt + SB+AG & $22.55 \pm 3.8$ & $<0.001 \dagger$ \\
MMP-2 ihnibitor & $4.53 \pm 1.2$ & N.S. ${ }^{*}$ \\
CisPt + MMP-2i & $26.64 \pm 5.8$ & $<0.001 \dagger$ \\
CisPt + MMP-2 i+AG & $25.38 \pm 5.8$ & $<0.0014 \dagger$ \\
DPI & $3.02 \pm 0.5$ & N \\
CisPt +DPI & $22.87 \pm 4.1$ & \\
\hline
\end{tabular}

